\title{
BROADSHEET BULLIES?:: DESIGNATED PUBLIC FORUM \\ AND ESTABLISHED NEWSPAPERS' EFFORTS TO RID \\ PHILADELPHIA'S PUBLIC TRANSIT SYSTEM OF A GOVERNMENT-SPONSORED COMPETITOR
}

\author{
MichaEl A. MUGMON ${ }^{\dagger}$ \\ INTRODUCTION
}

Almost as if a young mother had left her newborn child in a basket on the city's doorstep, I first noticed the bouncing baby of a newspaper on the ground outside the 22nd Street subway-surface station before my early morning ride to school. Tightly bundled against numerous other copies of the color tabloid, the newspaper's flag effectively doubled as a pinned note addressed to the newspaper's finders. Name? TPI Metro PA, or Metro for short. Date of birth? Monday, January 24, 2000. Birthplace? Philadelphia.

In August 1999, Metro's parents-the Southeastern Pennsylvania Transportation Authority (SEPTA) and publisher Transit Publications Inc., Metro PA ("TPI Metro PA")-had entered into a contract providing for SEPTA's exclusive distribution of Metro in SEPTA's paid areas, including platforms, buses, and trains. ${ }^{1}$ Because these areas were expressly off limits to all other newspapers, Metro would, for all intents and purposes, gain a captive audience of transit riders at the expense

* With all due apologies to the 1974 and 1975 Stanley Cup champion Philadelphia Flyers, the original "Broad Street Bullies."

${ }^{\dagger}$ B.A. 1999, J.D. Candidate 2002, University of Pennsylvania. I am indebted to Carrie Y. Flaxman for her tremendous assistance in locating documents crucial to the writing of this Comment. I would like to acknowledge Professor Seth F. Kreimer for his preliminary guidance and Professor Sarah Barringer Gordon for her invaluable encouragement, contagious enthusiasm, and boundless wisdom. I thank my parents, Marc and Ellen Mugmon, for their love and support, as well as my brother Matt for ensuring that journalistic ethics are alive and well. Finally, I express my gratitude to the editors of Volume 150 of the University of Pennsylvania Law Review for their diligence and professionalism on this piece and indeed on all others throughout the year.

${ }^{1}$ See Agreement for Rider Publications between Southeastern Pennsylvania Transportation Authority and Transit Publications Inc., Metro PA 11-12 (Aug. 5, 1999) (on file with author) [hereinafter Agreement for Rider Publications] (“[I]nitial distribution will focus on the heavily traveled high speed lines[,] . . commuter rail [lines,] ... subway-surface trolleys, ... buses[,] . . [and] stations."). 
of established newspapers' readership-a valuable commodity in the late twentieth century's shrinking newspaper market. ${ }^{2}$ Fearing perhaps that Philadelphians would adopt Metro as their own and lavish their attentions-and precious advertising dollars-on it, the City of Brotherly Love's established media conglomerates did not take kindly to their upstart sibling.

Three days before Metro's parents introduced their newspaper to the city, Philadelphia Newspapers, Inc., The New York Times Co., and the Gannett Satellite Information Network, Inc. (which publishes USA Today and The Reporter of Lansdale, Pennsylvania), filed suit against one of Metro's parents-SEPTA-in United States District Court for the Eastern District of Pennsylvania." Arguing that SEPTA's contract with TPI Metro PA to "distribute a SEPTA-sponsored newspaper in areas in which no other newspapers are permitted to be distributed, violates the First ... Amendment," the news organizations sought a temporary restraining order and/or a preliminary injunction to prevent the government agency from distributing the new publication. ${ }^{4}$ The publishers also charged that the contract gave SEPTA unconstitutional editorial control over the newspaper's content, ${ }^{5}$ and that it bur-

2 See, e.g., Felicity Barringer, Fissures in Sunday Papers' Pot of Gold, N.Y. TIMES, Nov. 6 , 2000, at Cl (reporting a marked decline in nationwide Sunday newspaper circulation and an $11 \%$ decline in weekday circulation since 1987); Chronicle Now SixthLargest Daily, HOUSTON CHRON., Nov. 4, 2001, Business, at 3 (showing an $8.6 \%$ decrease in average Philadelphia Inquirer weekday circulation from 392,438 to 358,801 during a one-year period ending September 30, 2001). Although the September 11, 2001, terror attacks on New York City and Washington, D.C., produced an immediate bump in national circulation numbers, the news events did not give national newspaper circulation a long-term shot in the arm. Compare Valerie Block, Media Hold Most of Sept. 11 Gains, CRAIN's N.Y. BUS., Dec. 3, 2001, at 3 (remarking that the three months following the attacks saw a major spike in circulation numbers for New York newspapers, countering a nationwide circulation dip over the past decade), and David Lieberman, $\mathrm{Na}$ tion Returns to Traditional News Outlets for Information, USA TODAY, Sept. 18, 2001, at 6B (speculating on an increase in circulation numbers after a huge jump in newsstand sales), with Gretchen A. Kirby, Looking Back, Looking Ahead: Uncertainties in the Paper Market Cause Print Buyers to Watch and Wait, PRINT MEDIA, Nov. 1, 2001, at 18 (quoting a paper company executive who "anticipate[s] a continued weakness in our order book for the fourth quarter" despite "an apparent temporary increase in newspaper circulation ... in the wake of the tragic events of September 11"), and Newspapers' Circulation Figures Show Mixed Bag, DALlas MORNING NEWS, Oct. 30, 2001, at 4D (reporting that four of Texas' five largest newspapers experienced circulation declines over the past year, while national numbers were varied).

${ }^{3}$ Memorandum of Law in Support of the Motion of Plaintiffs for a Temporary Restraining Order and/or Preliminary Injunction at 1, Phila. Newspapers, Inc. v. S.E. Pa. Transp. Auth. (E.D. Pa. Jan. 24, 2000) (No. 00-392) (on file with author).

${ }^{4}$ Id. at $2-3$.

${ }^{5}$ See id. at 11, 19 (contending that SEPTA's requirement of editorial control con- 
dened their constitutional right to distribute and circulate newspapers. $^{6}$ Most intriguing, the newspapers suggested that SEPTA potentially created a designated public forum "by intentionally opening a nontraditional forum for public discourse [to Metro]." If SEPTA indeed fashioned a designated public forum on platforms and in transit vehicles, the government agency could not exclude other newspapers constitutionally unless the distribution restriction was content-neutral, served a compelling interest and was narrowly tailored to achieve that interest, and left open substantial other means for communication.

Holding that the publishers had "failed to satisfy their burden of demonstrating that there is a reasonable probability of success on the merits and that Plaintiffs will suffer immediate and irreparable harm," U.S. District Court Judge Robert F. Kelly quickly denied the publishers' request. ${ }^{9}$ The newspapers appealed to the U.S. Court of Appeals for the Third Circuit and concurrently asked Judge Kelly for a temporary restraining order pending the appeal of his initial injunction denial-a request he denied on February 2, 2000. ${ }^{10}$ Nearly three weeks later, a three-judge panel of the Court of Appeals denied the newspapers' request to bar SEPTA temporarily from distributing Metro in areas forbidden to other publications." The combatants lay dormant-

stitutes unconstitutional invidious viewpoint discrimination).

${ }^{6}$ See id. at 16 ("SEPTA-a state actor-cannot burden plaintiffs' exercise of their constitutional right to distribute their newspapers by having a preferential scheme that accords greater distribution rights to one newspaper over [another newspaper] unless SEPTA can meet its burden to justify its action."). See generally Lovell v. City of Griffin, 303 U.S. 444, 452 (1938) (holding unconstitutional a state law regulating and inhibiting circulation of materials).

${ }^{7}$ Memorandum of Law in Support of the Motion of Plaintiffs for a Temporary Restraining Order and/or Preliminary Injunction at 27, Phila. Newspapers, Inc. v. S.E. Pa. Transp. Auth. (E.D. Pa. Jan. 24, 2000) (No. 00-392) (on file with author) (quoting Cornelius v. NAACP Legal Def. \& Educ. Fund, Inc., 473 U.S. 788, 802 (1985)).

${ }^{8}$ See, e.g., Perry Educ. Ass'n v. Perry Local Educators' Ass'n, 460 U.S. 37, 46 (1983) (outlining standards for constitutional speech restrictions in traditional and designated public forums); United States Postal Serv. v. Council of Greenburgh Civil Ass'ns, 453 U.S. 114, 132 (1981) (same); Consol. Edison Co. v. Pub. Serv. Comm'n, 447 U.S. 530, 535-36 (1980) (same).

${ }^{9}$ Phila. Newspapers, Inc. v. S.E. Pa. Transp. Auth., No. 00-392 (E.D. Pa. Jan. 24, 2000) (order denying preliminary injunction).

${ }^{10}$ Phila. Newspapers, Inc. v. S.E. Pa. Transp. Auth., No. 00-392, 2000 U.S. Dist. LEXIS 1160, at *5 (E.D. Pa. Feb. 2, 2000) (denying temporary restraining order pending appeal of the district court's initial preliminary injunction denial). Although Judge Kelly cited "strongly contested factual issues" in denying the injunction, id. at *3, he declined to discuss any constitutional issues in making the decision.

"Joseph A. Slobodzian, Newspapers' Appeal Is Rejected, PHILA. INQUIRER, Feb. 23, 2000, at C2 (reporting that the Third Circuit panel, in a one-sentence order, denied the newspapers' request for an injunction to halt the distribution of Metro). 
waiting for the district court to hear the case on its merits-until November 5, 2001, when SEPTA and the publishers reached an out-ofcourt settlement ending the dispute. ${ }^{12}$ Under the terms of the agreement, SEPTA may not give Metro any distribution preference on its property, except on buses, for eighteen months; should SEPTA want to afford Metro special distribution treatment following the expiration of that eighteen-month window, the agency must give the newspapers ninety days' notice or face the prospect of a renewed legal challenge. ${ }^{13}$ Nonetheless, the out-of-court settlement did not constitutionally ratify SEPTA's actions, and no court has ever debated the constitutional merits of the case.

Although the newspapers' publishers invoked grand and righteous First Amendment tenets in their briefs, ${ }^{14}$ this Comment focuses on a distinct-and possibly dispositive-aspect of First Amendment jurisprudence: public forum doctrine, and specifically the designated public forum doctrine.

More specifically, this Comment discusses the public forum doctrine and how it pertains to a deal between a public transit system and a private newspaper. Part I will explore how and why SEPTA inked a distribution deal with a private media organization. This portion first addresses SEPTA's motives for distributing a newspaper throughout its system, as well as the agency's historical approach to regulating expression, particularly newspaper and handbill distribution. An analysis of two recent agency-specific cases that directly pertain to public forums and expression within the SEPTA system prove helpful in understanding the approach SEPTA took in inking a distribution deal. ${ }^{15}$ This Part then progresses to the agency-promulgated SEPTA Rules Re-

${ }^{12}$ Joann Loviglio, Philadelphia Transit Tabloid and Newspapers Reach Settlement on Distribution, AP, Nov. 5, 2001, Westlaw (detailing the settlement agreement between SEPTA and the newspaper publishers).

${ }^{13}$ See id. (describing in full the settlement terms).

${ }^{14}$ See Memorandum of Law in Support of the Motion of Plaintiffs for a Temporary Restraining Order and/or Preliminary Injunction at 16, Phila. Newspapers, Inc. v. S.E. Pa. Transp. Auth. (E.D. Pa. Jan. 24, 2000) (No. 00-392) (on file with author) (arguing that SEPTA cannot burden the plaintiffs' exercise of their constitutional right to distribute their newspapers by granting Metro preferential distribution rights unless SEPTA can justify its action under the First Amendment, which SEPTA cannot do).

${ }^{15}$ See Christ's Bride Ministries, Inc. v. S.E. Pa. Transp. Auth., 148 F.3d 242, 248-52 (3d Cir. 1998) (determining that SEPTA created a designated public forum in its advertising space); Storti v. S.E. Pa. Transp. Auth., No. 99-2159, 1999 U.S. Dist. LEXIS 14515, at *25 (E.D. Pa. Sept. 10, 1999) (applying the SEPTA Rules Relating to Constitutionally Protected Activities to pamphlet distribution on station platforms, and holding SEPTA station platforms to be nonpublic forums), aff d, 265 F.3d 1056 (3d Cir. 2001) (unpublished table decision), cert. denied, 122 S. Ct. 1073 (2002). 
lating to Constitutionally Protected Activities, ${ }^{16}$ which govern the regulation of expressive conduct in paid areas and on platforms, and which were developed in response to constitutional challenges to SEPTA's expression policies. Finally, Part I will probe the details of the contract between SEPTA and TPI Metro PA, which simultaneously attempts both to satisfy the SEPTA Rules Relating to Constitutionally Protected Activities and to circumvent them.

Part II investigates public forum doctrine generally and designated public forum more specifically, looking into how a government agency transforms a nonpublic forum into a designated public forum. In Part III, this Comment analyzes how the designated public forum doctrine might have been applied in the SEPTA scenario, and more broadly, how it should apply in situations where a government agency has teamed up with a private newspaper in exclusive distribution deals. In this final Part, the Comment also touches on public policy concerns regarding a court's finding that a government agency created a designated public forum by signing an exclusive distribution deal.

This Comment, however, does not look into the constitutionality of a government contracting with a private newspaper; it focuses only on public forum issues once a government agency and private publisher have completed the deal. Metro has enjoyed tremendous success abroad and in Philadelphia thus far, ${ }^{17}$ and it is assumed for the purposes of this Comment that the American subsidiary of Metro's publisher could have financially withstood a court challenge yielding an adverse result and continued to print. It is further assumed that its publisher will seek to expand into other American markets and will face similar fights. ${ }^{18}$ Thus, this Comment centers around what hap-

${ }^{16}$ See S.E. Pa. Transp. Auth., SEPTA Rules Relating to Constitutionally PROTECTED ACTIVITIES 1 (1999) (on file with author) [hereinafter SEPTA RULES] (regulating expressive activities on SEPTA property).

${ }_{17}$ See Karen Abbott, Metro Celebrates Its First Anniversary, PHILA. WKLY., Jan. 31, 2001, at 14 ("[T]he paper has seemingly accomplished what it set out to do: become the newspaper of choice for people not accustomed to reading newspapers."). Despite the fact that Metro lost $\$ 8.8$ million in fiscal year 2000 , its parent company chalked up the loss to the "early stage of development at the newspaper" and reported a fourthquarter net sales increase of $21.7 \%$. Free Commuter Newspaper Loses $\$ 8.8 M$, PHILA. Bus. J., Feb. 2, 2001, available at http://philadelphia.bcentral.com/philadelphia/stories/ 2001/02/19/daily14.html.

18 Indeed, a Boston edition of Metro was launched on May 3, 2001, but the Massachusetts Bay Transportation Authority (MBTA) declined to link up with the upstart to provide for distribution on platforms and in paid areas. See Metro Hits Boston Market, PHILA. BUS. J., May 2, 2001 ("The Massachusetts Bay Transportation Authority refused 
pens when the deal is done; the issue then becomes whether, once a public transit system has agreed to an exclusive distribution deal, other newspaper publishers have the constitutional right to distribute and circulate their publications in areas expressly off-limits to outside newspapers.

Before delving into the history behind the arrangement, one should ask: Why does designated public forum doctrine even matter with regard to these deals? The initial application of the public forum doctrine in this realm will almost certainly dictate how courts will view exclusive distribution deals between private publications and public transit systems (if not all government agencies) across the nation. When one considers that the newspapers' suit against SEPTA indirectly headed off a deal between Metro and the Massachusetts Bay Transit Authority in Boston, ${ }^{19}$ and that Metro's handlers tentatively plan to expand into public transit systems in New York City, Chicago, and San Francisco, ${ }^{20}$ the significance of these deals becomes substantially more evident. A victory for Metro in any jurisdiction would essentially mean that the newspaper's publisher would likely face minimal subsequent legal challenges in striking exclusive distribution deals with other public transit systems. Not only would the result set a symbolic legal standard for the purposes of persuasive authority, but a transportation agency victory would undoubtedly raise the ire of national media conglomerates, ${ }^{21}$ whose monopolistic newspapers ${ }^{22}$ would face competition that could result in the loss of precious readership. ${ }^{23}$

a deal with Metro, perhaps affected by a lawsuit brought against SEPTA by [four publishers], which objected to the distribution of Metro through SEPTA stations and vehicles."), available at http://philadelphia.bcentral.com/philadelphia/stories/2001/04/ 30/daily30.html; Gabriel Spitzer, A Year Old, Metro Has Yet to Wow Philadelphia, MEdiA LIFE, Feb. 16, 2001 (reporting that "ethical issues involved in distributing newspaper to a captive audience of commuters" likely spooked the MBTA out of teaming up with Metro), available at http://www.medialifemagazine.com/news2001/feb01/feb12/5_fri/ news3Friday.html.

${ }^{19}$ See supra note 18 (detailing the Boston expansion story).

${ }^{20}$ See Doug Donovan, Coming to America, FoRBEs, May 29, 2000, at 70, 70 (discussing Metro's publisher's plans to expand into other markets); Judge Refuses to Stop Distribution of Metro, PA. L. WKLY., Jan. 31, 2000, at 2 (relating that Metro's parent company is eyeing other American public transit systems for distribution).

${ }^{21}$ See Donovan, supra note 20, at 70 (quoting a Metro attorney who believed that "[the] case [was] less about lofty First Amendment principles than economic bullying").

See Charles H. Tillinghast, american Broadcast Regulation and the FIRST AMENDMENT 107 (2000) ("[M]ost newspapers ... enjoy a monopoly status in their geographical areas.").

${ }^{29}$ See Barringer, supra note 2 (reporting faltering national newspaper circulation 
Because SEPTA's sponsorship of one newspaper to the exclusion of all others represents the first time a government agency has effectively controlled a private newspaper, the Philadelphia deal is utterly novel-and utterly important insofar as public forum doctrine is concerned, for the Supreme Court has never applied forum analysis to the platforms and paid areas of a public transit system. ${ }^{24}$

\section{ON DEEP BACKGROUND}

\section{A. SEPTA's Historical Approach to Restricting Expression}

Established by the Pennsylvania Urban Mass Transportation Law, ${ }^{25}$ SEPTA is the country's fifth-largest public transportation system. ${ }^{26}$ Serving "nearly one million" commuters daily throughout the 2200square-mile, five-county metropolitan area, ${ }^{27}$ the government agency reigns over public transportation in Philadelphia and its surroundings, providing extensive bus, subway, regional rail, subway-surface trolley, and paratransit service. ${ }^{28}$ With such a broad service area and large ridership base, SEPTA unquestionably has a deep interest in ensuring its riders' safe passage from one destination to another. ${ }^{29}$

numbers). Media tycoon Mort Zuckerman briefly published the free Daily News Express in New York City in 2001 as "a strategy ... to head off a possible invasion into New York by [Metro's publisher], which has had great success publishing editions of the free commuter daily Metro in cities throughout Europe." Jeff Bercovici, Mort KOs Free Daily News Express, MEDiA LIFE, Sept. 20, 2001, available at http:// www.medialifemagazine.com/news2001/sep01/sep17/4_thurs/news2thursday.html.

Zuckerman retired the Metro copycat-distributed during the afternoon and outside of major city transportation hubs-when the September 11, 2001, terrorist attacks on the World Trade Center destroyed the distribution site for nearly 20,000 copies of the newspaper (providing approximately one-fifth of its circulation). Id.

${ }^{24}$ Indeed, the high Court has never directly applied public forum analysis to the core of a subway or rail system. In Lehman v. City of Shaker Heights, 418 U.S. 298, 301-04 (1974), however, the Court discussed the question of advertising space on the side of city buses. Also, International Society for Krishna Consciousness, Inc. v. Lee, 505 U.S. 672, 680-85 (1992), may serve as a potentially relevant analogy, as the Court addressed airport terminals in light of the public forum doctrine.

25 PA. CONS. STAT. $\$ 1701-1785$ (1994).

${ }^{26}$ See Transportation, at http://www.philadex.com/trasnportation.asp [sic] (last visited Apr. 28, 2002) (providing general information regarding area transit service).

${ }^{27} \mathrm{Id}$.

${ }^{28}$ See id. (describing SEPTA services to prospective employees).

${ }^{29}$ See SEPTA Five Year Plan for Strategic Change, at http://www.septa.org/ reports/5year.html (last visited Feb. 25, 2002) (outlining SEPTA's plans for improving customer safety); see also Special Safety Message from SEPTA General Manager J. Leary (Oct. 4,2001 ) (reassuring riders made nervous by the September 11 terrorist attacks that "providing you with safe transportation each day remains our top priority"), available at 
With such a sentiment in mind, SEPTA officials have long prohibited newspaper sales on platforms and in the so-called "paid areas" of SEPTA property. ${ }^{30}$ Traditionally invoking a safety rationale, the agency has always forbidden "hawkers"-walking newspaper salespeople-from soliciting sales on transit vehicles and banned newsracks and newspaper boxes outright from both vehicles and paid areas. ${ }^{31}$ Indeed, SEPTA has emerged victorious in several cases challenging its expression regulations by arguing that the agency's "primary function" is not to "provide for expressive activities," but rather to maintain passenger safety and to move riders through the system efficiently. ${ }^{32}$

However, in Christ's Bride Ministries, Inc. v. Southeastern Pennsylvania Transportation Authority, the first of two recent cases to object to SEPTA's expression policies, a three-judge panel of the U.S. Court of Appeals for the Third Circuit found that SEPTA violated an advertiser's First Amendment rights when the agency removed a particularly graphic anti-abortion poster from advertising space in SEPTA's Suburban Station in Center City Philadelphia. ${ }^{99}$ The court agreed with Christ's Bride's assertion that SEPTA's advertising space amounts to a designated public forum; thus, the agency may only regulate the space through time, place, and manner restrictions and only if those restrictions are content neutral, survive strict scrutiny, and leave open

http://www.septa.org/news/20011004-20011231-2267.html (last visited Feb. 25, 2002). Not only does SEPTA have a policy interest in protecting its riders, but the agency also has a strong economic interest in safety. SEPTA recently agreed to pay $\$ 250,000$ to the family of a twelve-year-old boy killed on July 11, 2001, when he leaned out of a subway window and hit his head on a pole. See SEPTA Agrees to Pay Family After Boy's Death on Train, AP, Westlaw, Dec. 7, 2001 (recounting the incident). On December 15, 1999, a jury declared that SEPTA must pay $\$ 51$ million to a mother and her four-year-old son, whose foot was ripped off in a gruesome escalator accident at a SEPTA subway station. $\$ 51$ Million Jury Award Against SEPTA, PA. L. WKLY., Dec. 20, 1999, at 2; Claudia N. Ginanni, Documents Uncovered Mid-Trial Fuel \$51 Million Injury Verdict vs. SEPTA, LEGAL INTELLIGENCER, Dec. 15, 1999, at 1.

${ }^{30}$ See Shannon P. Duffy, Newspapers Challenge SEPTA's Deal with Metro, LEGAL INTELLIGENCER, Jan. 24, 2000, at 5 (highlighting SEPTA's tight restrictions on station and vehicle activities); Storti v. S.E. Pa. Transp. Auth., No. 99-2159, 1999 U.S. Dist. LEXIS 14515, at *4 (E.D. Pa. Sept. 10, 1999) (remarking on SEPTA's historical ban on distribution activities in "paid areas," places in which a rider would have to pay to gain access), aff d, 265 F.3d 1056 (3d Cir. 2001) (unpublished table decision), cert. denied, 122 S. Ct. 1073 (2002). tion).

${ }^{31}$ See Duffy, supra note 30 (explaining SEPTA's past policies on newspaper circula-

32 Storti, 1999 U.S. Dist. LEXIS 14515, at *9.

${ }^{33}$ See 148 F.3d 242, 257 (3d Cir. 1998) (concluding that the forum at issue is SEPTA's advertising space). 
ample alternate channels for communications. ${ }^{34}$ Although the case clearly does not involve newspaper distribution, its outcome not only affects how courts will apply public forum doctrine to SEPTA's expression restrictions, but the ruling against SEPTA - as well as a number of prior challenges to the agency's practices concerning expressive activities ${ }^{35}$-indirectly led the agency to promulgate a series of guidelines for agency regulation of expressive conduct. ${ }^{96}$

\section{B. How SEPTA Responded to Constitutional Challenges: SEPTA Rules Relating to Constitutionally Protected Activities}

On January 27, 1999, those guidelines arrived in the form of the SEPTA Rules Relating to Constitutionally Protected Activities. ${ }^{37}$ Realizing the need to "address requests to engage in commercial and noncommercial activities on the SEPTA system, in a fashion not inconsistent with Constitutional guarantees," ${ }^{38}$ former SEPTA General Manager John K. Leary Jr. and other agency officials provisionally decided to allow a limited set of expressive activities on SEPTA property. ${ }^{39}$ Not surprisingly, even such limited permitted conduct was accompanied by further ideological and policy-based restrictions-namely that no activity could unreasonably interfere with SEPTA's "primary function

${ }^{34}$ See id. at 252 (ruling that SEPTA's advertising space constitutes a designated public forum); see, e.g., Perry Educ. Ass'n v. Perry Local Educators' Ass'n, 460 U.S. 37, 45-46 (1983) (outlining standards for constitutional speech restrictions in traditional and designated public forums); United States Postal Serv. v. Council of Greenburgh Civic Ass'ns, 453 U.S. 114, 132 (1981) (same); Consol. Edison Co. v. Pub. Serv. Comm'n, 447 U.S. 530, 535-36 (1980) (same).

${ }^{35}$ See Memorandum of Law in Support of the Motion of Plaintiffs for a Temporary Restraining Order and/or Preliminary Injunction at 4, Phila. Newspapers, Inc. v. S.E. Pa. Transp. Auth., No. 00-392 (E.D. Pa. Jan. 24, 2000) (on file with author) (listing previous First Amendment challenges to SEPTA's expression rules).

${ }^{36}$ SEPTA RULES, supra note 16. The adverse outcome for SEPTA in Christ's Bride served as an impetus for the release of the Rules. In fact, the document had been in the works since the U.S. District Court for the Eastern District of Pennsylvania ruled a 1989 agreement establishing generally applicable rules for expressive conduct (especially leafleting) unenforceable. See Storti, 1999 U.S. Dist. LEXIS 14515, at *6-8 (relating the evolution of SEPTA policy concerning expressive activities); see also Frantz v. N.E. Commuter Servs. Corp., No. 97-6631, 1998 U.S. Dist. LEXIS 22764, at*12-15 (E.D. Pa. Nov. 17, 1998) (declaring a previous series of generally applicable rules relating to expressive conduct as unenforceable).

${ }^{37}$ SEPTA RULES, supra note 16.

${ }^{38}$ Memorandum from John K. Leary Jr. to General Manager's Staff (Jan. 27, 1999) (on file with author) (explaining reasons for promulgating the Rules Relating to Constitutionally Protected Activities).

${ }^{39}$ See SEPTA RULES, supra note 16, at 1 (setting forth a "Statement of Rationale" for the Rules). 
to provide a fast, reliable, and economical transportation system" and "service that is accessible, affordable, safe, reliable, clean and customer-focused. ${ }^{n 0}$ Almost certainly anticipating further constitutional challenges, the Rules' framers went so far as to interpret and apply the Rules in the context of fourteen "important and compelling governmental interests of SEPTA, ${ }^{, 41}$ most of which revolve around ensuring passenger safety and security, as well as preserving an orderly flow of traffic through stations and aboard transit vehicles. ${ }^{42}$ More specifically, the Rules completely ban handbilling and subject newspaper sales to extremely heavy regulation, requiring permits for distribution in unpaid areas. ${ }^{43}$ Although not exactly a rousing espousal of First Amendment ideals, the Rules nonetheless moved SEPTA from a position of absolute prohibition to one of tentative permission.

\section{Testing the New Rules}

With SEPTA's having opened this small hole, Nicholas Storti and Michael Perez attempted to leap through it. Storti and Perez filed suit to challenge the agency's newest prohibitions on handbilling on platforms and in paid areas. ${ }^{44}$ As in the Christ's Bride case, the situation did not involve newspaper distribution; Storti and Perez passed out relig-

${ }^{40} I d$.

${ }^{41}$ Id. The Court also has stated:

Although a State is not required to indefinitely retain the open character of the facility, as long as it does so it is bound by the same standards as apply in a traditional public forum. Reasonable time, place, and manner regulations are permissible, and a content-based prohibition must be narrowly drawn to effectuate a compelling state interest.

Perry Educ. Ass'n v. Perry Local Educators' Ass'n, 460 U.S. 37, 46 (1983); see also Carey v. Brown, 447 U.S. 455, 461-62 (1980) ("When government regulation discriminates among speech-related activities in a public forum, the Equal Protection Clause mandates that the legislation be finely tailored to serve substantial state interests and the justifications offered for any distinctions it draws must be carefully scrutinized."); RodNey A. SMOLla, FreE SPEECH IN AN OPEN SOCIETy 208 (1992) (discussing scrutiny levels for speech infringement).

${ }^{42}$ See SEPTA RULES, supra note 16, at 1-3 (cataloguing compelling interests for use by courts in applying strict scrutiny to restrictions in a public forum).

${ }^{43} I d$. at 6-7 (addressing circulation restrictions). The Rules conspicuously mention nothing about newspaper distribution in paid areas, strongly suggesting that SEPTA would roundly deny permit applications for newsracks and newspaper boxes in those special places.

${ }^{44}$ See Storti v. S.E. Pa. Transp. Auth., No. 99-2159, 1999 U.S. Dist. LEXIS 14515 (E.D. Pa. Sept. 10, 1999), at*1 (explaining plaintiffs' contention in broad terms), affd, 265 F.3d 1056 (3d Cir. 2001) (unpublished table decision), cert. denied, 122 S. Ct. 1073 (2002). 
ious literature on SEPTA property and sought to continue the practice. ${ }^{45}$ However, as opposed to Christ's Bride, the court had the opportunity to review the constitutionality of one provision of the SEPTA Rules (the anti-leafletting regulation) ${ }^{46}$ in light of the identical forum at issue in the controversy between the established newspapers and SEPTA." Asserting that "paid areas and platforms are "designated public fora' in which the government may only impose contentneutral restrictions on expression that are narrowly tailored to serve an important government interest," Storti and Perez charged that SEPTA's ban fails this strict test because the "prohibition is facially over-broad." Essentially, they objected to the handbilling ban on the grounds that SEPTA intended to (and did) create, at the very least, a limited public forum by historically allowing Krishnas to distribute handbills in the contested areas. ${ }^{49}$ The court rejected Storti and Perez's contentions, holding that although the agency permitted infinitesimal exceptions to the expression regulations, SEPTA did not manifest the requisite intent necessary to turn platforms and paid areas into designated public forums for leafletting purposes. ${ }^{50}$ Instead, the court reasoned, paid areas and platforms are nonpublic forums, ${ }^{51}$ under which expression regulations need only qualify as "reason-

45 See id. at *1, *3 (explicating plaintiffs' expressive actions).

${ }^{46}$ See SEPTA Rules, supra note 16, at 7-9 (banning handbill distribution in paid areas and on platforms).

${ }^{47}$ See Storti, 1999 U.S. Dist. LEXIS 14515, at *3 (suggesting that paid areas and platforms are designated public forums and thus that SEPTA is limited in its constitutional ability to regulate expressive conduct therein).

${ }^{48}$ See id. at $* 1, * 3$ (laying out a constitutional rationale for a verdict against SEPTA).

${ }^{49}$ See id. at $* 24-25$ (conveying the plaintiffs' view that SEPTA created a public forum). Such exceptions are, of course, for less controversial unpaid areas. See SEPTA RuLES, supra note 16, at 7 ("No person shall distribute or attempt to distribute such material on any platform or in any paid area ..." (emphasis added)). With regard to the Krishnas, in 1975, SEPTA accepted a consent decree that allowed the International Society of Krishna Consciousness ("ISKCON") to perform "sankirtan"-the ritual solicitation of funds-on all SEPTA property. Storti, 1999 U.S. Dist. LEXIS 14515, at *5. Following the promulgation of the Rules, SEPTA and ISKCON agreed that the Krishnas' actions would fall under the purview of the Rules. See id. at *7 (detailing the demise of SEPTA's two-tiered leafletting rules-one for the Krishnas and one for everyone else). A full discussion of designated public forum doctrine appears later in this Comment. Infra Part II.B.

${ }^{50}$ See Storti, 1999 U.S. Dist. LEXIS 14515, at *24 (noting that the exception for the Krishnas does not demonstrate the "government's intent and purpose" to establish a designated public forum). A lengthy discussion of how the government turns a nonpublic forum into a designated public forum follows in Part II.G.

${ }^{51}$ See Storti, 1999 U.S. Dist. LEXIS 14515, at *25 (categorizing paid areas and platforms as nonpublic forums). 
able." Notwithstanding the fact that the court's decision pertained only to the handbilling portion of the Rules, one could reasonably infer from this outcome that a court would hold that platforms and paid areas are not designated public forums for newspaper circulation purposes. The forum's landscape would change, however, after SEPTA teamed up with a private media conglomerate to distribute an agency-sponsored newspaper to the exclusion of all other newspaper.

\section{Sowing the Seeds of the Distribution Deal}

According to the SEPTA Five Year Plan for Strategic Change, agency officials quite plainly wanted to "improve customer service" through "[s]trengthening the lines of communication with the customer" and "disseminat[ing] information." 59 This goal was merely a piece of a larger objective to stem the tide of ridership losses between 1988 and 1996 and to control an "escalated operating deficit, calculated to increase by at least $\$ 192$ million for the years 1999 through 2003." Evidently, SEPTA officials intended to do what they could to reclaim part of the transit service's hemorrhaging ridership and to increase revenues concomitantly. With regard to the agency's expanding deficit, SEPTA officials also presumably feared that SEPTA's already precarious financial status could grow markedly worse; a pending suit involving the accidental amputation of a child's foot by a station escalator meant that the agency would face even greater fiscal woes if the jury tagged SEPTA for a major money verdict. ${ }^{55}$

Perhaps it should come as no surprise that SEPTA officials sought out a publication through which the agency could freely communicate with passengers, raise revenues, and overhaul its suffering public image. $^{56}$ Publishing a Request for Proposal (RFP) on June 8, 1999, for a "rider publication" for "on-system distribution," SEPTA pursued a newspaper or circular that would "promote[] SEPTA services and

${ }^{52}$ See Cornelius v. NAACP Legal Def. \& Educ. Fund, 473 U.S. 788, 806 (1985) ("Control over access to a nonpublic forum can be based on subject matter and speaker identity so long as the distinctions drawn are reasonable in light of the purpose served by the forum and are viewpoint neutral.").

${ }^{53}$ See SEPTA Five Year Plan for Strategic Change, supra note 29 (illustrating SEPTA's intent to foster communication between the agency and passengers).

${ }_{55}^{5}$ See id. (showing overall goals of the plan).

${ }^{55}$ See $\$ 51$ Million Jury Award Against SEPTA, supra note 29 (reporting that a jury decided that SEPTA must pay a substantial sum to a mother and her son, who lost his foot in a horrific SEPTA escalator accident).

${ }^{56}$ See SEPTA Five Year Plan for Strategic Change, supra note 29 (mentioning the goals of increasing revenues and improving public relations). 
generate[] revenue through the sale of advertising." ${ }^{\text {57 }}$ The RFP further demanded that "[e]ach issue should provide SEPTA with significant editorial coverage and must conform to SEPTA's editorial standards for content;" more specifically, at least three SEPTA news items must appear in every issue. ${ }^{58}$ SEPTA stated that it would not assume the costs of production, printing, delivery, or distribution. ${ }^{59}$ Thus, when a new corporation, "TPI Metro PA" responded to the RFP, SEPTA found itself in a highly fortuitous position for two reasons: not only was TPI Metro PA the lone publisher to respond favorably to the editorially stifling RFP, but it would accede gladly to all of SEPTA's demands and more-it would pay the agency a kingly sum for the exclusive opportunity to distribute a publication within the walls of the transit system. ${ }^{61}$

\section{E. Sailing to Philadelphia: Sweden's Modern Times Group Crosses the Atlantic with TPI Metro PA}

It is somewhat misleading, however, to classify TPI Metro PA as a new corporation. Although incorporated in Pennsylvania on May 5, $1999{ }^{62}$ TPI Metro PA actually operates as an American subsidiary of Modern Times Group (MTG), a powerful Stockholm-based media conglomerate that deals in virtually every communications medium. ${ }^{63}$ Most significantly, since 1995, MTG has published free transit dailies

${ }^{57}$ Request for Proposal by Southeastern Pennsylvania Transportation Authority (Aug. 5, 1999) [hereinafter Request for Proposal] (on file with author).

${ }^{38}$ Id.

${ }^{59}$ Id.

60 See Jerry Walker, Philadelphia to Get a New Daily Paper, JACK O'DWYER'S NEWSLETTER, Nov. 10, 1999, at 3 (reporting that TPI Metro PA "was the only bidder for the contract").

${ }^{61}$ See Technical Proposal by Transit Publications, Inc., Metro PA 15-16 (Aug. 5, 1999) [hereinafter Technical Proposal] (on file with author) (proposing a generous revenue and fee structure under which SEPTA would receive at least $\$ 45,000$ per month and one full page of space per issue, simply for allowing TPI Metro PA to distribute Metro throughout the system).

${ }^{62}$ See Memorandum of Law in Support of the Motion of Plaintiffs for a Temporary Restraining Order and/or Preliminary Injunction at 10, Phila. Newspapers, Inc. v. S.E. Pa. Transp. Auth. (E.D. Pa. Jan. 24, 2000) (No. 00-392) (on file with author) (describing TPI Metro PA's entry into the American marketplace).

${ }^{63}$ Shannon P. Duffy, Judge Refuses to Stop Distribution of Metro, LEGAL INTELLIGENCER, Jan. 25, 2000, at 1 (relating MTG's role in bringing Metro to Philadelphia). According to TPI Metro PA's technical proposal, "MTG conducts business in a variety of media: television; radio; newspaper; magazines; and the Internet as well as extensive production and distribution services. In 1998, MTG had revenues of $\$ 500$ million (US)." Technical Proposal, supra note 61, at 2. 
in twenty-two cities spanning fifteen countries, including the United States with Philadelphia's Metro. ${ }^{64}$ Beginning with Metro Stockholm in 1995, MTG entered into an arrangement with Stockholm Lokaltrafik, the city's regional public transportation system, to circulate a free daily in the subway system. The venture saw immense success. ${ }^{65}$ MTG since has replicated its initial Stockholm triumph by striking similar deals with public transit systems in Gothenburg, Prague, Budapest, and Helsinki, to name but a few. ${ }^{66}$ Unlike an American public transit agency, however, none of those transit systems must reconcile an exclusive distribution contract with the First Amendment's public forum doctrine. $^{67}$ In other words, setting up shop in Philadelphia-MTG's first American outpost-would not be painless.

\section{F. Metro's Parents Meet: Terms of the Deal and Implications}

Ignoring momentarily the vast legal implications of MTG's initial foray into the United States with Philadelphia's Metro, one must examine the terms of TPI Metro PA's agreement with SEPTA to produce and distribute Metro throughout the transit system. At its financial core, the five-year contract guarantees SEPTA at least $\$ 30,000$ per month in shared advertising revenues (plus two percent of annual adjusted gross advertising revenues), ${ }^{68}$ as well as at least $\$ 15,000$ per month in cleaning and recycling fees. ${ }^{69}$ Straddling the line between a substantive term and a monetary one, the deal also affords SEPTA a full page in each issue for announcements and news pieces, ostensibly "to provide public transit information to its riders"; the page's estimated value starts at $\$ 1.1$ million in the contract's first year, but esca-

${ }^{64}$ See Tabloid Dispute Heats Up, PHILA. MeTro, Feb. 22-24, 2002 (mentioning Metro's international pervasiveness); see also Duffy, supra note 63, at 1 (noting that MTG's publications spread across Europe and across the Atlantic).

${ }^{65}$ See Technical Proposal, supra note 61, at 3 ("Today, Metro Stockholm publishes 260,000 copies six . . . days a week for distribution throughout [Stockholm Lokaltrafik].").

See id. at 3-4 (discussing Metro's penetration of several European transit systems).

${ }^{67}$ But see Tabloid Dispute Heats Up, supra note 64, at 07 (reporting widespread union opposition to the means of distribution for a new French edition).

See id. (showing the revenue structure for the SEPTA-TPI Metro PA deal). Additional revenues "could equal almost $\$ 300,000$ " per year by the end of the five-year deal. Id.

${ }^{69}$ See id. (building clean-up costs in to the contract). Both parties wisely speculate that riders who pick up the newspaper to read on transit vehicles will not necessarily take it with them when they reach their final destinations, hence the difference between circulation and readership. 
lates to nearly $\$ 2.5$ million in year five. ${ }^{70}$ Aside from compensating SEPTA quite well, what else would TPI Metro PA have to do for the privilege of gaining exclusive access to the SEPTA system? Each weekday with the exception of holidays, TPI Metro PA would have to print and distribute at least 110,000 copies of Metro. ${ }^{71}$ As for the format of Metro itself, the newspaper would not be a traditional broadsheet, as are some of its competitors-the Philadelphia Inquirer serving as the most obvious example. Rather, Metro would exist as a smaller, twenty-four-page full-color tabloid that contains heavily edited national newswire articles, skeletal local stories, and splashy graphics, all meant for consumption during a twenty-five minute commute. ${ }^{72}$ of course, Metro would be absolutely free to all riders ${ }^{73}$ at its 850 distribution points, including stations and transit vehicles. ${ }^{74}$

Although these terms alone raise the nasty specter of "a government entity['s] tak[ing] control over [a private newspaper's] editorial content," ${ }^{75}$ SEPTA's demands for editorial dominion went even further. Notwithstanding the complimentary full page SEPTA would receive each issue (which TPI Metro PA, not SEPTA, suggested), SEPTA insisted on something far more intangible and far more unsettling: "significant editorial coverage" of SEPTA itself and external coverage that "must conform to SEPTA's editorial standards for content." Holding off again on the constitutional concerns of such an arrangement, one must question seriously the journalistic integrity of a government agency's forcing a private newspaper to adhere to an abstract

${ }^{70}$ Id.

${ }^{71}$ See id. (detailing circulation figures). Most recently, the Philadelphia Inquirer has reported Metro's circulation to stand at 150,000 newspapers daily. Slobodzian, supra note 11 .

${ }^{72}$ See, e.g., Jon Shure, Paper, Get Your Paper: All News We Fit to Print, 9 N.J. LAw. 231 (2001) (offering a colorful and concise description of Metro).

${ }^{73}$ See Technical Proposal, supra note 61, at 2 ("[TPI Metro PA] proposes to publish a high quality, free daily transit newspaper designed to be distributed within the SEPTA system for its commuters.").

${ }^{74}$ See Shure, supra note 72 , at 231 (reporting the widespread distribution throughout the SEPTA system).

${ }^{75}$ Proceedings at 7, Phila. Newspapers, Inc. v. S.E. Pa. Transp. Auth. (E.D. Pa. Jan. 24, 2000) (No. 00-392) (order denying preliminary injunction) (copy on file with author).

${ }^{76}$ Request for Proposal, supra note 57. The contract nowhere defines or further explicates what these "standards" are, although it does provide for TPI Metro PA to "take direction . . . from SEPTA's Project Representatives . . but . . remain solely professionally responsible for the services." Agreement for Rider Publications, supra note 1 , at 2 . 
governmental editorial standard. ${ }^{77}$ It may be safe to assume that the accidental amputation of a four-year-old boy's leg by a SEPTA escalator would not have received the same degree of scrutiny in Metro as it did in the traditional Philadelphia press. ${ }^{78}$ With regard to Metro's own coverage of the incident, the newspaper's editors certainly would have had an incentive to tone down coverage, especially considering that "coverage ... must conform to SEPTA's editorial standards for content." ${ }^{79}$ More worrisome under the contract, SEPTA officials theoretically could force Metro editors to eliminate coverage altogether. Moreover, they simultaneously could issue propaganda on SEPTA's own page in an effort to mollify riders' fears and concerns and to mobilize public support for the agency. ${ }^{80}$ This is, of course, to say nothing of the fact that once SEPTA riders enter the system, they have but one newspaper from which to choose: Metro.

\section{G. The Issue}

Even if SEPTA does control Metro editorially, and even if SEPTA officials can contractually use one page per issue however they please, the contractual terms, objectivity problems, and indeed the out-ofcourt settlement do not settle the crucial constitutional question of whether the public transit agency has created a designated public fo-

${ }^{77}$ See Memorandum of Law in Support of the Motion of Plaintiffs for a Temporary Restraining Order and/or Preliminary Injunction at 4, Phila. Newspapers, Inc. v. S.E. Pa. Transp. Auth. (E.D. Pa. Jan. 24, 2000) (No. 00-392) (on file with author) (intimating that readers could not trust Metro to be in any way objective in its coverage of SEPTA).

${ }^{78}$ See, e.g., $\$ 51$ Million Jury Award Against SEPTA, supra note 29 (detailing the verdict and the horrific accident); Ginanni, supra note 29 (same).

${ }^{79}$ Request for Proposal, supra note 57.

${ }^{80}$ This scenario is hardly farfetched. SEPTA has frequently used its page to trumpet its involvement in "Operation Lifesaver," a national program dedicated to rail and transit safety for school-age youth. See SEPTA Operation Lifesaver, at http:// www.septa.org/reports/lifesaver.html (last visited Apr. 28, 2002) (explaining Operation Lifesaver's mission and SEPTA's role in furthering it). As recently as November 6 , 2000, SEPTA officials seemed to employ spin tactics:

Newspaper articles and television reports from the Philadelphia area and around the country tell disturbing stories about unfortunate incidents involving children and railroad tracks. At SEPTA, we are concerned not only with the safety of our customers, but also our neighbors and the communities that surround the Authority's vast system. With so many schools and gathering places adjacent to SEPTA rail lines, we are especially concerned about the safety of the region's children.

Operation Lifesaver, METRO, Nov. 6, 2000, at 8. Undoubtedly, Operation Lifesaver is a noble cause, but how should we view SEPTA's intentions in light of previous accidents and the agency's editorial control of Metro? 
rum. Through the highly restrictive exclusive distribution contract, SEPTA has potentially engaged in "the business of promoting expression." ${ }^{\text {"81 }}$ When a public transit system enters into an exclusive distribution contract with a private publisher, and when the agency exerts control over the publication's content, does the physical system-specifically, its platforms, paid areas, and transit vehicles-become a designated public forum such that it may no longer prohibit competing publishers from selling their newspapers there?

\section{A PRIMER ON PUBLIC FORUM}

\section{A. Public Forum Doctrine Generally}

According to Harvard University's Henry Louis Gates, Jr., "the issue of speech management arises in the highly contested matter of 'public forum': where may one exercise these supposedly valuable rights of free speech? How much (if any) access to these forums will we enjoy? ${ }^{82}$ Developed under the First Amendment, ${ }^{83}$ the public forum doctrine essentially dictates when, where, and under which conditions individuals may engage in expressive conduct on public property. While the general principle seems relatively understandable,

${ }^{81}$ See Memorandum of Law in Support of the Motion of Plaintiffs for a Temporary Restraining Order and/or Preliminary Injunction at 21, Phila. Newspapers, Inc. (No. 00392). SEPTA essentially won Storti by arguing that its primary function was to deliver passengers safely and efficiently, not to protect or promote expression. See Storti v. S.E. Pa. Transp. Auth., No. 99-2159, 1999 U.S. Dist. LEXIS 14515, at *29-30 (E.D. Pa. Sept. 10, 1999) ("SEPTA has articulated and offered evidence to support specific and important reasons for its view that platforms and paid areas should be dedicated exclusively to transit use."), affd, 265 F.3d 1056 (3d Cir. 2001) (unpublished table decision), cert. denied, 122 S. C. 1073 (2002); see also Int'l Soc'y for Krishna Consciousness, Inc. v. Lee, 505 U.S. 672,682 (1992) (stating that one cannot argue "that an airport terminal has as a principal purpose promoting 'the free exchange of ideas" (quoting Cornelius v. NAACP Legal Def. \& Educ. Fund, Inc., 473 U.S. 788, 800 (1985)).

${ }^{82}$ Henry Louis Gates, Jr., Truth or Consequences: Putting Limits on Limits, in THE LIMITS OF EXPRESSION IN AMERICAN INTELLECTUAL LIFE 15, 16 (Am. Council of Learned Soc'ys Occasional Paper No. 22, 1993).

${ }^{83}$ See U.S. CONST. amend. I ("Congress shall make no law ... abridging the freedom of speech, or of the press ...."). In Gitlow v. New York, 268 U.S. 652, 666 (1925), the Supreme Court affirmed that the First Amendment was binding against the states by virtue of the Fourteenth Amendment. Therefore, as a state agency under Pennsylvania law, SEPTA must abide by the First Amendment. See 74 PA. Cons. STAT. $\$ \$ 1701$ 1785 (1994) (establishing SEPTA by state fiat).

${ }^{84}$ See generally DARIEN A. MCWHIRTER, FREEDOM OF SPEECH, PRESS, AND ASSEMBLY 30-42 (1994) (offering a particularly helpful overview of the public forum doctrine); THOMAS L. TEDFORD, FREEDOM OF SPEECH in THE UNITED STATES 254-89 (3d ed. 1997) (same). 
navigating the doctrine's "murk[y] waters" ${ }^{85}$ has never been easy. Although public forum doctrine has existed in its present tripartite form-traditional public forum, designated public forum, and nonpublic forum-since $1983,{ }^{86}$ inchoate forum analysis extends back over sixty years. ${ }^{87}$ In Hague v. CIO, the Supreme Court laid the groundwork for the modern notion of the traditional public forum by holding that public streets and parks shall remain free for "assembly, communicating thoughts between citizens, and discussing public questions." Because "use of the streets and public places has, from ancient times, been a part of the privileges, immunities, rights, and liberties of citizens," ${ }^{89}$ the government may not prohibit expressive conduct in those sacred areas; it may regulate activity only so far as necessary to maintain public order and to preserve the express purpose of the place in question. ${ }^{90}$ Two years later, in the 1941 decision of Cox $v$. New Hampshire, the Court first dictated the specific extent to which government may regulate these open forums. ${ }^{91}$ In finding that a group of Jehovah's Witnesses should have obtained a parade permit as required by statute before marching on public streets, the Court held that reasonable "time, place, and manner" regulations applied in a neutral fashion were wholly constitutional under the First Amendment. $^{92}$ The principles from this core set of cases ultimately evolved into the notion of the traditional public forum. ${ }^{93}$

${ }^{85}$ Gates, supra note 82 , at 16.

${ }^{86}$ See Perry Educ. Ass'n v. Perry Local Educators' Ass'n, 460 U.S. 37, 45-46 (1983) (distinguishing among traditional, designated, and nonpublic forums for the purposes of forum analysis).

${ }^{87}$ See Hague v. CIO, 307 U.S. 496, 516 (1939) (Roberts, J., in one of three opinions supporting the result) (striking down a municipal ordinance mandating permits for assembling in the city's public streets and parks).

Id. at 515.

${ }^{89}$ Id.

${ }^{90}$ See Schneider v. State, 308 U.S. 147, 162 (1939) (citing Hague and specifying that the government may regulate speakers' conduct lawfully).

${ }^{91}$ See 312 U.S. 569, 576-78 (1941) (upholding a state statute requiring the acquisition of a parade permit and the payment of a nominal fee to pay for security and maintenance of order during the proceedings).

92 Id. at 576; see also Lovell v. City of Griffin, 303 U.S. 444, 451 (1938) (finding a circulation ordinance invalid because it contains "no restriction in its application with respect to time or place"). Although the cases resulted in verdicts of a different stripe, Lovell is nonetheless the logical precursor to the more forceful Cox.

${ }^{93}$ See Perry, 460 U.S. at 45 (defining the traditional public forum). 


\section{B. Traditional Public Forum}

First of the three forums described by the Court in 1983 in Perry Education Ass'n v. Perry Local Educators' Ass'n, the traditional public forum occupies a sacrosanct position in forum doctrine in that the government may not ban all expressive conduct in these constitutionally holy locales. ${ }^{94}$ Under traditional public forum analysis, courts shall apply a strict scrutiny test to determine whether a governmental restriction on expressive conduct may stand. ${ }^{95}$ Essentially, "[the government] may ... enforce regulations of the time, place, and manner of expression which are content-neutral, are narrowly tailored to serve a significant government interest, and leave open ample alternative channels of communication."

\section{1. “Time, Place, and Manner"}

With "time, place, and manner," the Court merely lifted key language from Cox $v$. New Hampshire to permit expression restrictions on traditional public forums based on important public interests. ${ }^{97}$. Under this test, "[ $\mathrm{t}]$ he crucial question is whether the manner of expression is basically incompatible with the normal activity of a particular place at a particular time. ${ }^{, 98}$ Although courts typically approach First Amendment restrictions with profuse skepticism, they are more will-

${ }^{94}$ See id. (describing further limitations on governmental action within the confines of a traditional public forum).

${ }^{95}$ See id. (concluding that courts shall judge governmental regulations on a traditional public forum by a standard of strict scrutiny).

96 Id. The Court has delineated the various terms of the test to be used in evaluating a public forum speech. See also United States Postal Serv. v. Council of Greenburgh Civic Ass'ns, 453 U.S. 114, 132 (1981) (holding that mailboxes are not traditionally a public forum); Consol. Edison Co. of N.Y. v. Public Serv. Comm'n of N.Y., 447 U.S. 530,535 (1980) ("[T]he essence of time, place, or manner regulation lies in the recognition that various methods of speech, regardless of their content, may frustrate legitimate governmental goals."); Grayned v. City of Rockford, 408 U.S. 104, 115-16 (1972) (considering the "weighty reasons" for which a municipal government may limit the right to demonstrate on a public sidewalk near a school); Cantwell v. Connecticut, 310 U.S. 296,308 (1940) (holding that the right to "peacefully ... impart his view to others" protected an individual who chose to play a phonograph record criticizing all organized religions at a volume that did not disturb the public in any way); Schneider v. State, 308 U.S. 147, 167 (1939) (finding the municipal interest in preventing fraud insufficient to justify requiring government authorization to distribute pamphlets to private homes).

97 See Kent R. Middleton \& Bill F. Chamberlin, The law of Public COMMUNICATION 67-71 (1988) (providing an overview of "time, place, and manner" regulations under public forum analysis).

${ }_{98}$ Grayned, 408 U.S. at 116. 
ing to give the green light to regulations that simply funnel speech into proper times and locations rather than limit or modify its substance. ${ }^{99}$ Hence, courts generally "balance freedom of expression against such public interests as health, safety, the smooth flow of traffic, and a pleasing environment" ${ }^{\prime 00}$ as they take into account "the "nature of the place' and the pattern of its normal activities."101

\section{a. Content-Neutral}

With regard to the "time, place, and manner" test itself, courts must consider four factors in evaluating the constitutionality of a particular regulation. First, a time, place, and manner restriction may not discriminate as to the communicative content itself or as to the beliefs of the communicator. ${ }^{102}$ Through imposing this "contentneutral" requirement, the Supreme Court ensures that government does not "act[] as censor, undertak [ing] selectively to shield the public from some kinds of speech on the [arbitrary] ground that they are more offensive than others."

In Heffron v. International Society for Krishna Consciousness, Inc., for example, the Court upheld a "time, place, and manner" restriction because it did not touch on the content of the material that Krishnas attempted to distribute to Minnesota state fair attendees. ${ }^{104}$ However, in the Christ's Bride case, the Third Circuit declared SEPTA's decision to remove pro-life advertisements from its station walls unconstitutionally violated the content-neutral portion of the test. ${ }^{105}$ Thus, in the

99 See Middleton \& Chamberlin, supra note 97, at 67 (evaluating American courts' position on "time, place, and manner" restrictions on speech).

100 Id. at 70.

101 Grayned, 408 U.S. at 116 (quoting Charles Alan Wright, The Constitution on the Campus, 22 VAND. L. REV. 1027, 1042 (1969)).

${ }^{102}$ See Erznoznik v. City of Jacksonville, 422 U.S. 205, 209 (1975) ("A State or municipality may protect individual privacy by enacting reasonable time, place, and manner regulations applicable to all speech irrespective of content." (emphasis added).

${ }^{103} I d$. at 209.

104 See 452 U.S. 640,649 (1981) ("[T] he [r]ule applies evenhandedly to all who wish to distribute and sell written materials or to solicit funds. No person or organization, whether commercial or charitable, is permitted to engage in such activities except from a booth rented for those purposes.").

${ }^{105}$ See Christ's Bride Ministries, Inc. v. S.E. Pa. Transp. Auth., 148 F.3d 242, 255 (3d Cir. 1998) ("[T]he government 'may not grant the use of a forum to people whose views it finds acceptable, but deny use to those wishing to express less favored or more controversial views. And it may not select which issues are worth discussing or debating in public facilities." (quoting Police Dept. of Chicago v. Mosley, 408 U.S. 92, 96 (1972))). 
SEPTA-TPI Metro PA situation, the question would revolve around whether SEPTA's exclusion of all newspapers but Metro constitutes a regulation based on content. ${ }^{106}$

\section{b. Compelling government interest}

Second, typical of strict scrutiny tests, a "time, place, and manner" restriction must serve a significant, compelling, or important governmental interest. ${ }^{107}$ Under this hypothetically broad umbrella, the Court has placed interests such as ensuring the public health, maintaining of public order, and providing for the regular operations of government entities. ${ }^{108}$ To rely on Heffron once more, the Court valued the state's significant interest in pedestrian traffic flow and safety above the Krishnas' First Amendment right to circulate pamphlets to state fair attendees. ${ }^{109}$ Recognizing that the Court has categorized the management of crowd traffic flow at a state fair a significant government interest, one must look to the SEPTA scenario and ask if SEPTA could invoke orderly crowd movement in a public transit system as a significant government interest in restricting newspaper distribution, where the government agency has already permitted the distribution of one newspaper. ${ }^{110}$

${ }^{106}$ This query, of course, only matters if a court determines that platforms and paid areas are traditional public forums or designated public forums, though not nonpublic forums. This distinction will be discussed in depth. Infra Part II.C-D.

${ }^{107}$ See Va. State Bd. of Pharmacy v. Va. Citizens Consumer Council Inc., 425 U.S. 748, 771 (1976) ("We have often approved [of 'time, place, and manner'] restrictions ... provided that ... they serve a significant governmental interest ....").

${ }^{108}$ See MIDDLETON \& CHAMBERLIN, supra note 97, at $69-70$ (exploring the "significant government interest" requirement in terms of "time, place, and manner" restrictions).

${ }^{109}$ See Heffron, 452 U.S. at 650-53 (classifying the state's interests in crowd control and public safety as significant government objectives).

${ }_{10}$ Indeed, the Supreme Court has never specifically classified crowd flow and safety in a public transit system as a significant government interest, though it has done so in the context of an airport terminal. See Int'l Soc'y for Krishna Consciousness, Inc. v. Lee, 505 U.S. 672, 684 (1992) (holding that, although New York City airports are not public forums, the government had a compelling state interest in ensuring "the normal flow of traffic" in an airport where "[d] elays may be particularly costly"). This is not to say that the Court would automatically analogize airports to public transit systems, as in the latter fares cost substantially less and transportation options are more frequent if a delay results in a missed bus or trolley. 


\section{c. Narrow tailoring}

Examined in tandem with the second "time, place, and manner" criterion, the third factor mandates that a limiting regulation be narrowly tailored to accomplish a significant government interest; in other words, the government may impose only the "narrowest" of restrictions to meet a compelling state goal." Because this Comment specifically deals with newspaper distribution (albeit in a public transit system), it will prove helpful to study briefly this factor as applied to newspaper boxes.

In another case involving Philadelphia-area newspaper distribution, Philadelphia Newspapers, Inc. v. Borough of Swarthmore, ${ }^{112}$ a federal district court considered the constitutionality of a Swarthmore, Pennsylvania, municipal ordinance that almost completely barred newspaper boxes from the city's public sidewalks. ${ }^{113}$ Contending that the borough's significant interests in stemming the tide of commercialization and in maintaining unhampered pedestrian passageways vindicated the restrictive statute, Swarthmore's representatives sought to prove the old adage that the ends justified the means. ${ }^{114}$ In legal terms, they tried to convince the court that the regulation was narrowly tailored to meet compelling city objectives. Although the court ultimately did categorize aesthetic preservation and safe pedestrian movement as significant government interests, ${ }^{115}$ it struck down the ordinance on the basis that the ordinance did not fit those important goals narrowly enough. ${ }^{116}$

Thus, in order to classify paid areas, platforms, and transit vehicles as a public forum in a SEPTA-style situation, a court would have to determine that the agency's contract with the publisher to limit distribution to Metro only is sufficiently narrow to pass constitutional muster in light of the agency's stated interests in providing safe, efficient transit

"1' See Perry Educ. Ass'n v. Perry Local Educators' Ass'n, 460 U.S. 37, 45 (1983) (specifying the requirement that the government narrowly tailor regulations restricting speech to meet compelling government interests).

112381 F. Supp. 228 (E.D. Pa. 1974).

113 See id. at 235-36 (describing the ordinance at issue).

114 See id. at 242-43 (describing Swarthmore's justifications for the existence of such a restrictive distribution ordinance).

115 Id. at 244.

116 See id. at 243-44 (holding the ordinance violative of the First Amendment because it did not pass the strict scrutiny test). For a lovely description of this case, see MIDDLETON \& CHAMBERLIN, supra note 97, at 71. 
and maintaining orderly traffic flow. Yet, these rationales could very well fly out the window if a court noticed that SEPTA itself permitted distribution of one newspaper-the Metro-in seeming opposition to these undoubtedly important principles.

\section{d. "Ample alternative means of communication"}

According to the Court in Perry, the final piece of the "time, place, and manner" strict scrutiny test involves whether "ample alternative means of communication" exist. ${ }^{117}$ A regulation cannot stand in a public forum if the communicator does not have other adequate ways to reach a particular audience. ${ }^{118}$ With regard to the case that spawned this triumviral forum doctrine, the Perry Court examined a collective-bargaining agreement between a town's board of education and a union that had been elected as the exclusive bargaining representative for the school district's teachers. ${ }^{119}$ Under the terms of the agreement, the union would gain exclusive access to the district's interschool mail system and to teacher mailboxes. ${ }^{120}$ A rival union sued the elected union and several members of the school board on the grounds that the representative union's preferential access to the district's mail system violated the First Amendment. ${ }^{121}$ Although the Court decided that the mail system was a nonpublic forum in which "time, place, and manner" concerns matter substantially less, ${ }^{122}$ the Court nonetheless fleshed out why the rival union had "ample alternative means of communication." ${ }^{123}$ Through "means rang[ing] from bulletin boards to meeting facilities to the United States mail," the Court wrote that "[the rival union] is assured of equal access to all

${ }^{117}$ See Perry, 460 U.S. at 45 (setting forth a final permissible method by which the government may restrict expressive conduct in a public forum).

${ }^{118}$ See MidDLETON \& CHAMBERLIN, supra note 97 , at 71 (“[A] time, place, and manner restriction is permissible only if there are sufficient alternative channels of communication to the one restricted.").

${ }^{119}$ See Perry, 460 U.S. at $38-41$ (defining the terms of the collective bargaining agreement).

${ }^{120}$ See id. at 40 (explicating the contractual terms giving one union exclusive access to the district's teachers within district facilities).

${ }^{121}$ See id. at 41 (illustrating the rival union's embryonic forum argument).

${ }^{122}$ See id. at 46 (categorizing the interschool mail system as a nonpublic forum). This Comment soon discusses a nonpublic forum in contrast to the two types of public forums. Infra Part II.C.

${ }^{123}$ See Perry, 460 U.S. at 53 (showing why, even if the Court were to apply the "time, place, and manner" test used in restrictions on communication in public forums, the collective bargaining agreement would pass constitutional muster). 
modes of communication." 124

Returning once more to the agreement between SEPTA and TPI Metro PA, one must ask if the exclusivity provision of the contract leaves open ample alternative means of communication for the newspapers to reach SEPTA riders.

\section{Import}

Whether a court were to classify SEPTA's paid areas, platforms, and transit vehicles as a public forum is of key significance. Because "access rights have been enforced most vigilantly in the ... public forum," ${ }^{25}$ it tremendously behooves the established newspapers to show that SEPTA indeed created some type of a public forum.

\section{Nonpublic Forum}

At the other end of the Perry forum spectrum sits the nonpublic forum. ${ }^{126}$ "[Nonpublic forums] consist of publicly owned facilities that have been dedicated to use for either communicative or noncommunicative purposes, but that have never been designated for indiscriminate expressive activity by the general public." ${ }^{27}$ Simply put, nonpublic forums comprise all government property that is not a traditional public forum or a designated public forum. ${ }^{28}$ Starting from the premise that the "First Amendment does not guarantee access to property simply because it is owned or controlled by the government," Perry Court remarked that the government "may reserve [a nonpublic forum] for its intended purposes, communicative or otherwise, as long as the regulation on speech is reasonable and not an effort to suppress expression merely because public officials oppose the

${ }^{124}$ Id.; see also Greer v. Spock, 424 U.S. 828, 839 (1976) (holding that a restriction barring political campaigning on a military base was valid because "members of the Armed Forces stationed at Fort Dix are wholly free as individuals to attend political rallies, out of uniform and off base"); Pell v. Procunier, 417 U.S. 817, 827-28 (1974) (upholding a prohibition on prisoners' providing face-to-face interviews with the media, as the prisoners could communicate with the media via mail and through visitors).

${ }^{125}$ DOM CARISTI, EXPANDING FREE EXPRESSION IN THE MARKETPLACE 49 (1992).

${ }^{126}$ See Perry, 460 U.S. at 46 (describing the notion of the nonpublic forum).

${ }_{127}$ SMOLLA, supra note 41 , at 210.

128 See Perry, 460 U.S. at 46 (defining the nonpublic forum by the process of elimination). The designated public forum is an appellation that will be discussed in the following section, Part II.D.

${ }^{129}$ United States Postal Serv. v. Council of Greenburgh Civic Ass'ns, 453 U.S. 114, 129 (1981). 
speaker's view."130 Broadly stated, the test allows the government to restrict expression within a nonpublic forum, provided that the regulation is "viewpoint neutral and 'reasonable in light of the purpose served by the forum." ${ }^{131}$ The Court has included as nonpublic forums (and thus upheld regulations restricting expressive conduct with regard to) military bases, ${ }^{132}$ airport terminals, ${ }^{193}$ and even charity drives. $^{134}$

In Perry, the Court held that because the school district's interschool mail system qualified as a nonpublic forum, a collective bargaining agreement between the board of education and an elected teachers' union constitutionally could exclude all other unions from access to the mail system. ${ }^{135}$ "Implicit in the concept of the nonpublic forum," the Perry Court wrote, "is the right to make distinctions in access on the basis of subject matter and speaker identity. These distinctions may be impermissible in a public forum but are inherent and inescapable in the process of limiting a nonpublic forum to activities compatible with the intended purpose of the property."

Although the restriction at issue in Perry initially appears startlingly similar to the restrictive access situation involving SEPTA and TPI Metro PA, one can distinguish between the two scenarios quite clearly.

130 Perry, 460 U.S. at 46.

131 Christ's Bride Ministries v. S.E. Pa. Transp. Auth., 148 F.3d 242, 247 (3d Cir. 1998) (quoting Cornelius v. NAACP Legal Def. and Educ. Fund, Inc., 473 U.S. 788, $806(1985))$.

${ }^{132}$ See Greer v. Spock, 424 U.S. 828, 839 (1976) (holding that a policy barring political campaigning on a military base is valid).

${ }^{133}$ See Int'l Soc'y for Krishna Consciousness, Inc. v. Lee, 505 U.S. 672, 692-93 (1992) (declaring that restrictions on expression in New York City airport terminals may be constitutional); Atlanta Journal \& Constitution v. City of Atlanta Dep't of Aviation, 277 F.3d 1322, 1326 (11th Cir. 2002) (concluding summarily that an airport qualifies as a nonpublic forum).

${ }^{134}$ See Comelius, 473 U.S. at 806 (holding that the Combined Federal Campaign, an annual appeal to federal employees for charitable contributions, was a nonpublic forum).

${ }^{135}$ See Perry, 460 U.S. at 48 ("Because the school mail system is not a public forum, the School District had no 'constitutional obligation per se to let any organization use the school mail boxes." (quoting Conn. State Fed'n of Teachers v. Bd. of Educ. Members, 538 F.2d 471, 481 (2d Cir. 1976)).

${ }^{136} I d$. at 49 . Nonetheless, when the government restricts speech in a nonpublic forum, it may not do so in an "arbitrary, capricious or invidious" fashion. United States v. Kokinda, 497 U.S. 720, 725-26 (1990) (quoting Lehman v. City of Shaker Heights, 418 U.S. 298, 303 (1974)); see also United States v. Playboy Entm't Group, Inc., 529 U.S. 803, 818 (2000) ("When First Amendment compliance is the point to be proved, the risk of non-persuasion-operative in all trials-must rest with the Government ...."). 
The SEPTA matter involves newspaper distribution rather than pamphlet circulation among interschool mailboxes. Moreover, SEPTA has retained editorial control over distributed materials, whereas the interschool mail system in Perry merely acted as a conduit for the union's transmission of information. As to specific forum determination in the SEPTA-TPI Metro PA matter, the more difficult question would involve reconciling the federal district court's classification of SEPTA's paid areas and platforms in Storti v. Southeastern Pennsylvania Transportation Authority as nonpublic forums ${ }^{197}$ with the theory that the established newspapers should nonetheless enjoy the same access to paid areas and platforms that Metro does. ${ }^{138}$

\section{Designated Public Forum}

\section{Overview}

Situated between the traditional public forum and the nonpublic forum in Perry's tripartite forum scheme, the designated public forum shares much in common with the traditional public forum, but it occupies a more tenuous place in the realm of free expression on public property. ${ }^{139}$ Superficially, the main difference between a traditional public forum and a designated public forum may be stated as follows: "The Court has found some areas to be public forums because they have traditionally been used by Americans for speech activities. Other areas have become public forums ... because governments ... have allowed speech activities to take place there." ${ }^{140}$ However, once the government intentionally opens property to the public for expressive conduct, the same strict standards that apply to governmental regulations apply to regulations in a traditional public forum. Thus, in in-

${ }^{137}$ See No. 99-2159, 1999 U.S. Dist. LEXIS 14515, at *25 (E.D. Pa. Sept. 10, 1999) (classifying paid areas and platforms as nonpublic forums for leafletting purposes), aff'd, 265 F.3d 1056 (3d Cir. 2001) (unpublished table decision), cert. denied, 122 S. Ct. 1073 (2002).

${ }^{198}$ See infra Part III.A.1 (discussing fully the difference between Storti and Philadelphia Newspapers, and illustrating that newspaper distribution is distinguishable from handbilling, even though the public property at issue is the same).

139 See Perry, 460 U.S. at 46 (explaining that the government is "not required to indefinitely retain the open character" of designated public forums); see also CARISTI, supra note 125, at 66 ("[T] he government need not keep [designated public forums] open indefinitely. ...”); G. Sidney Buchanan, Toward a Unified Theory of Governmental Power to Regulate Protected Speech, 18 CoNN. L. REV. 531, 569 (1986) (explaining that there is no guaranteed right of public access to a "nontraditional forum" such as a designated public forum).

${ }^{140}$ MCWHIRTER, supra note 84, at 33. 
vertising space by “expressly' dedicating its advertising space to 'speech activity." 147 A subset of the designated public forum, the limited public forum is "open only to certain kinds of expression." Therefore, in Christ's Bride, the court deemed the station's advertising space a limited public forum because it pertained only to advertising. The idea of a limited public forum will prove exceedingly useful in distinguishing the SEPTA-TPI Metro PA case from Storti, in which the federal district court held that paid areas and platforms do not constitute public forums for the purposes of leafletting. ${ }^{149}$

Even within the confines of what looks like a limited public forum, the Supreme Court has indicated that the real distinction is between "general access" and "selective access." ${ }^{150}$ If the government has permitted a particular class of communicators to have "general access" to property, it has created a designated public forum. ${ }^{151}$ Widmar again provides the best example of a government entity providing "general access" to a certain group of speakers. ${ }^{152}$ If, however, the government has done "no more than reserve eligibility for access to the forum to a particular class of speakers, whose members must then ... 'obtain permission' to use it," then it has permitted only "selective access" and has not created a designated public forum. ${ }^{153}$ For Philadelphia's established newspapers, this hurdle would have proven slightly more substantial to overcome, as the SEPTA Rules Relating to Constitutionally

${ }^{147}$ Christ's Bride Ministries, Inc. v. S.E. Pa. Transp. Auth., 148 F.3d 242, 248 (3d Cir. 1998) (quoting United States v. Kokinda, 497 U.S. 720, 726-27 (1990)).

${ }_{148}$ Id. at 249; see also Rosenberger v. Rector \& Visitors of the Univ. of Va., 515 U.S. 819, 830 (1995) (deeming a student activities fund a limited public forum); Kreimer v. Bureau of Police, 958 F.2d 1242, 1261 (3d Cir. 1992) (considering a public library a limited public forum for "reading, writing and quiet contemplation," as opposed to "oral and interactive" expressive conduct).

${ }^{149}$ See Storti v. S.E. Pa. Transp. Auth., No. 99-2159, 1999 U.S. Dist. LEXIS 14515, at *29 (E.D. Pa. Sept. 10, 1999) (ruling SEPTA's paid areas and platforms nonpublic forums with regard to handbilling), affd, 265 F.3d 1056 (3d Cir. 2001) (unpublished table decision), cert. denied, 122 S. Ct. 1073 (2002).

${ }^{150}$ See Arkansas Educ. Television Comm'n v. Forbes, 523 U.S. 666, 679-80 (1998) (discussing designated public forum in terms of the distinction between "general access" and "selective access"” (quoting Cornelius v. NAACP Legal Def. \& Educ. Fund, 473 U.S. 788, 803, 805 (1985))).

${ }^{151}$ See Ark. Educ. Television Comm'n, 523 U.S. at 679-80 (defining "general access" in light of public forum analysis).

${ }^{152}$ See Widmar v. Vincent, 454 U.S. 263, 267 (1981) (holding that a state university making its meeting facilities generally available to student groups transforms the property into a designated public forum).

${ }^{153}$ See Ark. Educ. Television Comm'n, 523 U.S. at 679-80 (drawing a distinction between "'general access"" and "selective access," which typically does not lead to the creation of a public forum (quoting Comelius, 473 U.S. at 804)). 
vestigating the designated public forum, the umbilical query revolves around whether the government has transformed a nonpublic forum into a designated public forum. ${ }^{141}$

To understand how government transforms a nonpublic forum into a designated public forum, one must study several examples of designated public forums, categorized as such because the government has changed their character. In Widmar $v$. Vincent, the Supreme Court struck down the University of Missouri at Kansas City's policy barring religious groups from using its meeting facilities. ${ }^{142}$ Although the state university's meeting facilities certainly did not qualify as a traditional public forum, ${ }^{143}$ the Court believed that once the university made its facilities available to student groups generally, the facilities turned into a public forum such that the university could not discriminate at the expense of religious groups. ${ }^{144}$ The lesson from Widmar is that once the government creates a public forum, it may not pick and choose communicators based on the speaker's viewpoint or the content of the speech; $;{ }^{145}$ moreover, the strict scrutiny test applies all the same. ${ }^{146}$

\section{Limited Public Forum}

Significant as a case involving SEPTA, Christ's Bride differs from Widmar because the particular forum at issue is different. The Third Circuit held that the public transit agency created a designated public forum-or, more specifically, a limited public forum-in station ad-

141 The importance of this distinction cannot be overstated; it could prove dispositive with regard to the SEPTA-TPI Metro PA contract. See SMOLLA, supra note 41, at 211 ("The difficulty in modern public forum law is determining whether a facility falls within [the designated public forum appellation], and is thus subject to strict scrutiny, or [the nonpublic forum category], and is thus subject to the significantly more lax reasonable nexus test.").

${ }^{142}$ See Widmar v. Vincent, 454 U.S. 263, 277 (1981) (finding that the university could not exclude religious groups from meeting facilities once the university had opened them to other groups).

${ }^{149}$ See Widmar, 454 U.S. at 267 (discounting summarily the notion that the university's meeting facilities were a traditional public forum). The meeting facilities certainly do not resemble the "streets and public places" at issue in Hague. Hague v. CIO, 307 U.S. 496, 515 (1939).

144 See Widmar, 454 U.S. at $267 \mathrm{n} .5$ (explaining the rationale for deeming the meeting facilities a designated public forum).

${ }^{145}$ Id. at 269-70; see also MCWHIRTER, supra note 84, at 33 ("The one thing government may not do is allow one group to use an area for speech activities and deny access to other groups.").

${ }^{146}$ See Perry Educ. Ass'n v. Perry Local Educators' Ass'n, 460 U.S. 37, 45-46 (1983) (providing the constitutional standard for regulations in a designated public forum). 
Protected Activities do not ban newspaper distribution outright in the system as a whole. ${ }^{154}$ Nonetheless, SEPTA's very own sponsorship of an exclusive newspaper-as well as its relegation of newspapers to "free" areas-might have provided the necessary legal boosts.

\section{E. Defining the Forum in Question}

Although determining exactly how the government creates a public forum remains ambiguous, it is clear that a court shall define the forum at issue by the "access sought by the speaker." 155 This inquiry serves both to demarcate the disputed forum and to avoid either permitting or prohibiting government regulations on expressive conduct in an overly expansive area. ${ }^{156}$ Thus, in Lehman v. City of Shaker Heights, the Supreme Court winnowed down the forum in question from a public transit system as a whole to the advertising card space on the side of city buses. ${ }^{157}$ Similarly, in the Christ's Bride case, rather than defining the contested forum as SEPTA's entire Suburban Station, the court determined that the parties battled over a significantly more limited area: SEPTA's advertising space. ${ }^{158}$

Because courts have typically reduced the size of the contested forum, the Supreme Court has never applied public forum analysis to a subway or rail system as a whole, nor to its paid areas and platforms. ${ }^{159}$

${ }^{154}$ See SEPTA RULES, supra note 16, at 6 (allowing, theoretically, newspaper distribution by permit in "specified locations within designated areas" of the SEPTA system). Even though the Rules leave open the possibility of access to "designated" areas, they foreclose access to paid areas and platforms. Thus, SEPTA's permissive stance is entirely empty.

${ }^{155}$ CARISTI, supra note 125, at 45; see also Cornelius, 473 U.S. at 801 (deciding that the Combined Federal Campaign-not the whole federal workplace - was the forum in question).

${ }^{156}$ See generally Comelius, 473 U.S. at 801 (rationalizing implicitly the definition of a forum based on access sought by the speaker).

${ }^{157}$ See 418 U.S. 298, 303 (1974) (delineating narrowly the disputed forum).

${ }^{158}$ See Christ's Bride Ministries, Inc. v. S.E. Pa. Transp. Auth., 148 F.3d 242, 248 (3d Cir. 1998) (determining that SEPTA created a designated public forum in its advertising space).

${ }^{159}$ Although the Court has never applied forum analysis to an entire public transit system, it has, as evidenced by Lehman, employed the analysis with respect to different facets of a transit system. See Lehman, 418 U.S. at 303 (focusing only on bus advertising space). Generally, courts in transit cases examine whether the government can regulate communicative activities within station and vehicle advertising spaces, as well as in displays. See, e.g., N.Y. Magazine v. Metro. Transp. Auth., 136 F.3d 123, 130 (2d Cir. 1998) (holding, similarly to Lehman, that the "advertising space on the outside of buses is a designated public forum"); Lebron v. Nat'l R.R. Passenger Corp., 69 F.3d 650, 65556 (2d Cir. 1995) (narrowing the relevant public forum from Penn Station as a whole 
Recently, however, the Court aberrantly deemed New York City airport terminals the relevant forum at issue, holding that those terminals are nonpublic forums in which the government has substantial leeway to regulate expressive activity. ${ }^{160}$ Closer to home, the federal district court in Storti appeared to analogize to Lee in declaring that paid areas and platforms-the very forum in question in Philadelphia Newspapers, Inc. v. Southeastern Pennsylvania Transportation Authority ${ }^{161}$ constituted the relevant forums for analysis. ${ }^{162}$ There is, therefore, little question that the relevant forums with regard to the SEPTA-TPI Metro PA exclusive distribution contract are SEPTA's paid areas (including transit vehicles) and platforms. The pivotal inquiry, once again, would revolve around whether SEPTA created a designated public forum for the purposes of newspaper distribution.

\section{F. Creating a Designated Public Forum}

Deductively, virtually any public forum that the government actively creates will be a designated public forum; traditional public forums are indeed "traditional" because the government need not act affirmatively to permit them to exist. ${ }^{169}$ To state a difficult proposition

to one billboard in particular); Air Line Pilots Ass'n v. Dept. of Aviation, 45 F.3d 1144, 1151-52 (7th Cir. 1995) (determining that an airport diorama display case, rather than the entire concourse, comprised the forum at hand).

${ }^{160}$ See Int'l Soc'y for Krishna Consciousness, Inc. v. Lee, 505 U.S. 672, 683 (1992) (considering the constitutionality of handbilling and solicitation restrictions in airport terminals). Ultimately, the Court upheld the solicitation regulations but refused to rule on the leafleting provisions, since a prior case disposed of the matter. Id. at 685 .

${ }^{161}$ See Memorandum of Law in Support of the Motion of Plaintiffs for a Temporary Restraining Order and/or Preliminary Injunction at 18, Phila. Newspapers, Inc. v. S.E. Pa. Transp. Auth. (E.D. Pa. Jan. 24, 2000) (No. 00-392) (on file with author) (pointing to "SEPTA's stations and transit vehicles" as the relevant forums).

${ }_{162}$ See Storti v. S.E. Pa. Transp. Auth., No. 99-2159, 1999 U.S. Dist. LEXIS 14515, at *21-22 (E.D. Pa. Sept. 10, 1999) (declaring that it is "reasonable" to "assume that it is the paid areas and/or platforms themselves" that comprise "the proper unit for forum analysis"), aff'd, 265 F.3d 1056 (3d Cir. 2001) (unpublished table decision), cert. denied, 122 S. Ct. 1073 (2002).

${ }^{163}$ See Hague v. CIO, 307 U.S. 496, 515 (1939) ("Wherever the title of streets and parks may rest, they have immemorially been held in trust for the use of the public and, time out of mind, have been used for the purposes of assembly, communicating thoughts between citizens, and discussing public questions."); see also SMOLLA, supra note 41, at 209 ("[T] he government is not permitted to avoid the reach of [strict scrutiny] by 'privatizing' its traditional open forums."). The statement, of course, does not include the possibility of a government building a park or paving a new sidewalk, in which case both would count as traditional public forums by their nature. See TEDFORD, supra note 84, at 264 (describing the special nature of "quintessential" public forums). 
succinctly, " $[w]$ hat triggers the public forum is its deliberate use as a place for the exchange of views among members of the public." ${ }^{164}$ In a case involving a school principal's prior review and ultimate deletion of articles from a public high school student newspaper, the Supreme Court provided its most pristine explanation of how the government creates a public forum. ${ }^{165}$ Determining in Hazelwood School District $v$. Kuhlmeier that the relevant forum at issue consisted of public school facilities, the Court expressed the view that public school facilities become a public forum "only if school authorities have "by policy or by practice' opened those facilities 'for indiscriminate use by the general public' or by some segment of the public." ${ }^{166}$ The Court's "policy or practice" language necessarily requires an analysis of the government's "intent with regard to the forum in question," nated public forum is created because the government so intends." 168

However, as the Third Circuit has suggested, the government's stated intent is not alone dispositive when determining whether it has created a public forum. ${ }^{169}$ In its intent inquiry, the court must ask whether the government entity has "expressly" devoted the relevant forum to "speech activity." 170 While neither official passivity nor tolerance of "limited discourse" automatically establishes a public forum, ${ }^{171}$ the mere fact that the government has placed restrictions on a forum's use does not categorically signify that the government has intended to classify the forum as nonpublic. ${ }^{172}$ Perhaps the government has either imposed valid "time, place, and manner" regulations ${ }^{173}$ or

164 WARREN FreEdMAN, FREEDOM OF SPEECH ON PRIVATE PROPERTY 40 (1988).

${ }_{165}$ Hazelwood Sch. Dist. v. Kuhlmeier, 484 U.S. 260, $269-70$ (1988).

${ }^{106}$ Id. at 267 (quoting Perry Educ. Ass'n v. Perry Local Educators' Ass'n, 460 U.S. $37,47(1983))$.

${ }_{167}$ Christ's Bride Ministries, Inc. v. S.E. Pa. Transp. Auth., 148 F.3d 242, 248 (3d Cir. 1998).

${ }_{168} I d$. at 248.

${ }^{169}$ See Gregoire v. Centennial Sch. Dist., 907 F.2d 1366, 1374 (3d Cir. 1990) (stating that the fact that the government has expressly retained control over a forum's categorization through its policy statements does not alone resolve the forum issue). If the government's statement of intent were indeed authoritative, then it could keep a forum closed merely by stating its desire to do so. Moreover, courts could take into account neither the government's contradictory policies and practices nor inferred intent.

${ }^{170}$ United States v. Kokinda, 497 U.S. 720, $726-27$ (1990) (plurality opinion).

${ }^{171}$ Cornelius v. NAACP Legal Def. \& Educ. Fund, 473 U.S. 788, 802 (1985).

${ }^{172}$ See Christ's Bride, 148 F.3d at 249-50 (explaining the metamorphosis of a nonpublic forum into a public one).

${ }^{173}$ See Cox v. New Hampshire, 312 U.S. 569, 576 (1941) (permitting such regulations in public forums). See generally supra Part II.B. (discussing valid restrictions in 
formed a limited public forum "open only to certain kinds of expression." 174

In situations in which the government has not explicitly expressed its desire to open a forum to a certain mode of expression, courts may infer intent from a government entity's actions. ${ }^{175}$ Courts will most frequently "infer an intent on the part of the government to create a public forum where the government's justification for the exclusion of certain expressive conduct is unrelated to the forum's purpose."176

In a quintessential designated public forum case, the Court held in Widmar $v$. Vincent that a state university's action of opening school meeting facilities to all student groups implicitly created a public forum such that the school could not bar religious groups from using the facilities. Thus, a government entity need not provide an "unmistakably clear" statement of its desire to construct a public forum. ${ }^{177}$

\section{THE SEPTA ANGLE}

\section{A. Did SEPTA Create a Designated Public Forum?}

\section{Parameters}

As the Third Circuit aptly commented in Christ's Bride, most "difficult is the question whether SEPTA has created a designated public forum" "178 such that it may not exclude other newspapers from its paid areas and platforms. Although the district court's injunction denial intimates that SEPTA did not establish a public forum by cooperating with TPI Metro PA, ${ }^{179}$ a district court's injunction denial certainly does

public forums).

${ }^{174}$ Christ's Bride, 148 F.3d at 249.

${ }^{175}$ See Widmar v. Vincent, 454 U.S. 263, 267 (1981) (ruling that a state university created a public forum via its permissive actions).

${ }^{176}$ United Food \& Commercial Workers Union, Local 1099 v. S.W. Ohio Reg'l Transit Auth., 163 F.3d 341, 351 (6th Cir. 1998).

${ }^{177}$ Congress may abrogate the States' Eleventh Amendment immunity to suit pursuant to section $\mathbf{5}$ of the Fourteenth Amendment only if it provides an "unmistakably clear" statement of its intent to do so. See Dellmuth v. Muth, 491 U.S. 223, 230 (1989) (quoting Atascadero State Hosp. v. Scanlon, 473 U.S. 234, 242 (1985)). In examining governmental intent in public forum analysis, the bottom line remains that courts require far less explicit language.

178 148 F.3d at 248.

${ }^{179}$ See Phila. Newspapers, Inc. v. S.E. Pa. Transp. Auth., No. 00-392, 2000 U.S. Dist. LEXIS 1160, at *1 (E.D. Pa. Feb. 2, 2000) ("Plaintiffs failed to satisfy their burden of demonstrating that there is a reasonable probability of success on the merits."). Nonetheless, Judge Kelly also wrote that " $[t]$ his does not mean that Plaintiffs will be unable 
not dictate how future courts would or should rule on the merits of a case. Although the Storti court already defined SEPTA's paid areas and platforms as nonpublic forums with respect to handbilling, ${ }^{180}$ Storti would not control in this scenario because its result applies only to the leafletting provision of the SEPTA Rules Relating to Constitutionally Protected Activities - not to the Rules' provision restricting the "Sale of Newspapers and Other Written Materials." ${ }^{181}$ More specifically, through the concept of the limited public forum, the government can establish a designated public forum by making property generally available to a defined class of speakers; ${ }^{182}$ theoretically, newspaper distributors could circulate materials freely, whereas pamphleteers could not. These preliminary conclusions, however, serve only to permit a broader inquiry into the SEPTA-TPI Metro PA contract, as well as SEPTA's actions and manifested intent. The results show that SEPTA implicitly illustrated its intent to create a public forum by exclusively circulating a full-service newspaper over which it retained full editorial control.

\section{SEPTA Did Not Express Intent to Open a Public Forum}

In terms of express intent, SEPTA certainly did not state an intention to open a forum to all newspapers when it promulgated the SEPTA Rules Relating to Constitutionally Protected Activities on January 27, 1999. ${ }^{183}$ If anything, SEPTA officials nakedly displayed their desire to

ultimately to prevail on the merits." Id.

${ }^{180}$ See Storti v. S.E. Pa. Transp. Auth., No. 99-2159, 1999 U.S. Dist. LEXIS 14515, at *25 (E.D. Pa. Sept. 10, 1999) (deeming SEPTA's paid areas and platforms nonpublic forums for the purposes of leafleting and similar activities), affd, $265 \mathrm{~F} .3 \mathrm{~d} 1056$ (3d Cir. 2001) (unpublished table decision), cert. denied, $122 \mathrm{~S}$. Ct. 1073 (2002).

${ }^{181}$ See SEPTA RuLES, supra note 16, at 6-7 (regulating the distribution of publications, "including the sale of newspapers or other written material through 'honor' boxes or other similar units"). The Storti plaintiffs challenged solely the antihandbilling provision of the Rules. Recall that the government can create a limited public forum and open that forum only with respect to certain types of expressive conduct, or to a class of speakers. Simply because the government opens a forum to one mode of communicative activity does not signify that the disputed forum can withstand all constitutionally protected communicative activities. But see supra notes $142-45$ and accompanying text (discussing a case that holds that once a public forum is created the government cannot exclude a group based on the content of the speech or the speaker's viewpoint).

${ }^{182}$ See Ark. Educ. Television Comm'n v. Forbes, 523 U.S. 666, 679-80 (1998) (discussing designated public forums in terms of the distinction between "'general access" and "selective access" (quoting Cornelius v. NAACP Legal Def. and Educ. Fund, 473 U.S. 788, 803, 805 (1985))) .

${ }^{189}$ See SEPTA RULES, supra note 16, at 6-7 (limiting newspaper distribution 
keep paid areas and platforms closed forums, relying heavily on safety and crowd-flow concerns. ${ }^{184}$ Moreover, the Rules' Preamble clearly evinces the agency's intent to "permit certain expressive activities," but only to the extent that they do not interfere with "SEPTA's primary function to provide a fast, reliable, and economical transportation system." ${ }^{185}$ In Storti, SEPTA prevailed by arguing that agency regulations were intricately connected to this aim; ${ }^{186}$ essentially, SEPTA did not dedicate paid areas and platforms to "the promotion of expression.",187 Consistent with the agency's transit and safety goals, SEPTA itself could (and does) constitutionally distribute schedules and route maps in paid areas and on platforms. Similarly, if SEPTA had not granted TPI Metro PA the exclusive right to distribute a newspaper over which SEPTA retained editorial control, the government agency undoubtedly could constitutionally bar all newspaper distribution on its platforms and in its paid areas. As in Storti, a federal district court would likely uphold the provision of the Rules restricting newspaper distribution in light of pressing safety, security, and traffic flow rationalesnot to mention SEPTA's "primary function" of operating an efficient transit system. ${ }^{188}$ Looking to the Supreme Court's decision in International Society for Krishna Consciousness, Inc. v. Lee, a lower court would probably analogize the airport terminal considered in that case to a public transit system's paid areas and platforms and reach the conclusion that they constituted nonpublic forums for the purpose of newspaper distribution. ${ }^{189}$ If only SEPTA hadn't thrown a newsprint-laden

throughout the SEPTA system through strict permit and location restrictions).

${ }^{184}$ See id. at 2 (citing security and pedestrian traffic as overwhelming objectives behind the Rules).

${ }^{185}$ Id. at 1.

${ }^{186}$ See Storti v. S.E. Pa. Transp. Auth., No. 99-2159, 1999 U.S. Dist. LEXIS 14515, at *26, *29-30 (E.D. Pa. Sept. 10, 1999) (justifying the agency's handbilling restriction by looking to "SEPTA's interests in ensuring passenger safety and maintaining unhindered pedestrian traffic flow on the narrow and confined platforms" and by concluding that paid areas and platforms "'don't count among their purposes the "free exchange of ideas"' (quoting Int'l Soc'y for Krishna Consciousness, Inc. v. Lee, 505 U.S. 672, 686 (1992) (O'Connor, J., concurring))), affd, 265 F.3d 1056 (3d Cir. 2001) (unpublished table decision), cert. denied, 122 S. Ct. 1073 (2002).

${ }_{187}$ See Krishna Consciousness, 505 U.S. at 682 (recognizing that the objective of a public airport terminal was "the facilitation of passenger air travel, not the promotion of expression").

${ }_{188}$ See Storti, 1999 U.S. Dist. LEXIS 14515, at *17-18 (invoking Krishna Consciousness to categorize SEPTA's platforms and paid areas as nonpublic forums for the purpose of leafletting).

${ }^{189}$ See Krishna Consciousness, 505 U.S. at 682 (looking to the essential character of the forum to determine its categorization). This designation assumes that a public 
wrench into the pristine hypothetical.

\section{SEPTA Implied Its Intent to Open a Public Forum}

By entering into a deal with TPI Metro PA to distribute Metro exclusively within the confines of the SEPTA system, and by retaining editorial control over the publication, SEPTA completely changed the character of the disputed forum by itself engaging in "the promotion of expression." Accordingly, SEPTA may exclude other publishers from circulating their newspapers only through valid, content-neutral "time, place, and manner" regulations. ${ }^{191}$ Although the government agency manifested no express intent to open the forum to other newspaper distributors, its actions-its "'policy [and] practice" "'192 imply exactly the opposite.

In its RFP, SEPTA called upon an external publisher to "provide a rider publication, which promotes SEPTA services." PA incorporated that term alone into a contract with SEPTA, the distribution of a new publication likely would not have created a public forum. SEPTA's intent and goal (and presumably the final product) would have been sufficiently close to the stated purpose of the forum to justify its own existence as well as the concurrent ban on other publications. However, both the RFP and the contract's terms reveal that SEPTA entered the newspaper business lock, stock, and barrel, collecting advertising revenues and retaining the final say over editorial content. ${ }^{194}$ By cooperating with TPI Metro PA, SEPTA shifted away from its stipulated primary purpose of safely moving passengers to the alternate goals of collecting revenues and, more importantly, promoting expression.

transit system had not made a policy or practice of permitting distribution, only to change the rules midstream. If the Court could hold that a multipurpose, shopping mall-like public airport terminal constituted a nonpublic forum, then a lower court would almost certainly conclude that the purpose-focused paid areas and platforms of a transit system were no different.

${ }^{190}$ See id. (using the purpose of "the promotion of expression" as a bellwether of intent).

${ }^{191}$ See supra Part II.B (discussing valid government regulations on expressive conduct in traditional public forums).

${ }^{192}$ Hazelwood Sch. Dist. v. Kuhlmeier, 484 U.S. 260, 267 (1988) (quoting Perry Educ. Ass'n v. Perry Local Educators' Ass'n, 460 U.S. 37, 47 (1983)).

193 Request for Proposal, supra note 57.

${ }^{194}$ See id. (requesting a publication that "generates revenue through the sale of advertising"); id. at 10 ("Metro will conform to SEPTA's editorial standards of content."). 


\section{Exclusive Distribution Deals and Triggering a Public Forum}

May one extrapolate from this conclusion that a government agency that enters into a similar exclusive distribution deal automatically triggers the opening of a forum? Yes, but with one significant exception: Civilian Enterprise Newspaper (CEN) contracts. ${ }^{195}$ The Department of Defense may award exclusive CEN deals to private publishers to distribute newspapers to personnel on American military bases. $^{196}$ Although these CEN contracts seem logically to create public forums because of official "promotion of expression," 197 courts have long upheld the validity of CENs in the face of the public forum doctrine. ${ }^{198}$ Due to the unique nature of the military's objectives and the traditional deference courts give to defense restrictions against expression, ${ }^{199}$ "a special standard of review properly governs constitutional challenges to military regulations." ${ }^{\text {N200 }}$ National defense considerations, including the need of commanding officers to communicate with their troops, overwhelmingly justifies the preferential treatment given to CENs; one could hardly argue that SEPTA's desire to reach its passengers even rivals the military's absolute need for clear information transmission.

${ }^{195}$ See Memorandum of Law in Support of the Motion of Plaintiffs for a Temporary Restraining Order and/or Preliminary Injunction at 24 n.12, Phila. Newspapers, Inc. v. S.E. Pa. Transp. Auth. (E.D. Pa. Jan. 24, 2000) (No. 00-392) (on file with author) (distinguishing CEN contracts from the TPI Metro PA-SEPTA contract).

${ }^{196}$ See 32 C.F.R. $\$ 247$ (2001) (providing for CEN contracts in which the Department of Defense contracts with a commercial, civil publisher to distribute exclusively one newspaper on a military base, and allowing the newspaper to consist of both traditional news items and special military information).

${ }^{197}$ See Int'l Soc'y for Krishna Consciousness, Inc. v. Lee, 505 U.S. 672, 682 (1992) (noting that "Port Authority management considers the purpose of the [airport] to be the facilitation of passenger air travel, not the promotion of expression").

${ }^{198}$ See, e.g., Swarner v. United States, 937 F.2d 1478, 1482 (9th Cir. 1991) ("[T]he CEN must have a preferred distribution status compared to other free newspapers to accomplish the program's objectives."); Shopco Distrib. Co. v. Commanding General of Marine Corps Base, Camp Lejeune, N.C., 885 F.2d 167, 174 (4th Cir. 1989) (validating the existence of a CEN in light of important military objectives); M.N.C. of Hinesville, Inc. v. U.S. Dep't of Def., 791 F.2d 1466, 1476 (11th Cir. 1986) ("'The CEN is a special newspaper.' The military has an interest in distributing it to its personnel material that is not otherwise readily available." (citation omitted)).

${ }^{199}$ See Greer v. Spock, 424 U.S. 828, 838 (1976) (holding that military bases are nonpublic forums because "the business of a military installation ... [is] to train soldiers, not to provide a public forum").

${ }^{200}$ Bryant v. Secretary of the Army, 862 F. Supp. 574, 579 (D.D.C. 1994). 


\section{SEPTA's Exclusive Distribution Deal Opened a Public Forum}

If " $[w]$ hat triggers the public forum is its deliberate use as a place for the exchange of views among members of the public," ${ }^{201}$ then the expansion of Metro's content beyond mere transit information and even agency-bolstering propaganda to full news coverage, editorials, and letters-to-the-editor sections demonstrates a substantial exchange of views and thus opened the forum at least to newspaper distributors. In short, when SEPTA inked the exclusive distribution deal, it implicitly devoted the forum to a certain type of speech activity-namely newspaper production and distribution-and created a limited public forum. $^{202}$

\section{B. Does SEPTA's Exclusion of All Newspapers but Metro Withstand Strict Scrutiny?}

Having created a limited public forum, SEPTA would now have to pass the "time, place, and manner" strict scrutiny test for regulations in a public forum in order for its Rules provision banning newspaper distribution to pass constitutional muster. ${ }^{203}$ First, a court would have to find that SEPTA's "place" regulation is content-neutral. ${ }^{204}$ Quite obviously, SEPTA's actualization of this policy is anything but contentneutral. Originally, SEPTA may have prohibited newspaper distribution in its paid areas and on its platforms based on genuine and compelling safety and forum-purpose concerns. ${ }^{205}$ However, SEPTA officials completely contradicted these valid objectives when they contracted with TPI Metro PA to distribute one newspaper to the exclusion of all others and when they obtained editorial oversight of Metro's content. Although SEPTA spokesman Jim Whitaker said that SEPTA would “'have no control over anything [except a single page devoted to SEPTA],",206 the deal clearly stipulated that “[e]ach issue

201 See supra note 162 and accompanying text (explaining how the government can open a forum).

${ }^{202}$ See supra notes 164-67 and accompanying text (discussing how a government entity manifests its implicit intent to create a public forum).

${ }^{203}$ See supra Part II.B (setting forth the test for valid expression regulations in a traditional public forum).

${ }^{204}$ See Erznoznik v. City of Jacksonville, 422 U.S. 205, 209 (1975) ("A State or municipality may protect individual privacy by enacting reasonable time, place, and manner regulations applicable to all speech irrespective of content.").

${ }^{205}$ See SEPTA RULES, supra note 16, at 1-2 (enumerating SEPTA's key interests in promulgating the Rules).

${ }^{206}$ Duffy, supra note 30 , at 10 . 
should provide SEPTA with significant editorial coverage and must conform to SEPTA's editorial standards for content. ${ }^{207}$ Additionally, the deal's financial terms inextricably tie SEPTA's share of the profits to Metro's advertising success. ${ }^{208}$ Accordingly, by metamorphosing into a full-fledged publisher, SEPTA gained a strong incentive to close its system to other newspapers that would compete with Metro for readers and advertising dollars-and to other newspapers that would take SEPTA to task for mismanagement, irresponsible spending, and perhaps even constitutional violations relating to expressive conduct. Essentially, SEPTA officials could hardly contend that the Rules' mass newspaper exclusion is content-neutral where they have prohibited those newspapers for the very reason that they are not Metro.

Second and third, the excluding regulation must be narrowly tailored to meet a compelling government objective. ${ }^{209}$ Taking the latter portion before the former, one can reasonably conclude that SEPTA's express interests in "protecting the physical safety of patrons," "providing an environment in which its patrons are free from undue distraction from their primary purpose for being there," and "in preserving unobstructed, unimpeded, and orderly flow of pedestrian traffic" indeed constitute compelling objectives. ${ }^{210}$ Nonetheless, SEPTA's actualization of the Rules' newspaper provision unmistakably does not narrowly fit these important objectives. If SEPTA officials truly valued these goals, and if they legitimately believed that a ban on newspaper distribution in paid areas and on platforms would best serve to accomplish them, then why would they agree to the distribution of a newspaper in the very areas they sought to protect? In other words, can officials argue with a straight face that safety and crowd-flow concerns are paramount when Metro's distribution potentially presents the problems against which SEPTA expressly aimed to protect? SEPTA's policies are highly inconsistent with its practice and are not narrowly tailored to meet those compelling government objectives.

${ }^{207}$ Request for Proposal, supra note 57

${ }^{208}$ See supra note 68 and accompanying text (discussing the financial terms of SEPTA's contract with TPI Metro PA).

${ }^{209}$ See supra notes 107,111 , and accompanying text (relating a strict scrutiny test for regulations on expression in a public forum).

${ }^{210}$ SEPTA RuLES, supra note 16, at 1-2; see also Heffron v. Int'l Soc'y for Krishna Consciousness, Inc., 452 U.S. 640, 650-54 (1981) (classifying the state's interest in crowd control and public safety as significant government objectives).

${ }^{211}$ Now that SEPTA has placed Metro distribution bins in the entranceways of buses and subway-surface trolleys, pedestrian traffic flow is neither "unimpeded" nor "unobstructed," as the Rules so explicitly mention. SEPTA RULES, supra note 16, at 2. 
Finally, regardless of whether SEPTA has provided "ample alternative means of communication," ${ }^{212}$ the anti-distribution regulation fails other portions of the strict scrutiny test. To wit, the agency likely did provide adequate other modes of distribution for the excluded newspapers. Although the established newspapers lost a "captive audience" of readers in the forum at issue, publishers could distribute their newspapers throughout SEPTA's free areas ${ }^{218}$-not to mention on public sidewalks immediately outside stations. ${ }^{214}$ Furthermore, over Justice Douglas's impassioned dissent in Public Utilities Commission v. Pollak, ${ }^{215}$ the Supreme Court declared that streetcar riders do not qualify as a captive audience with regard to the broadcasting of radio programs in transit vehicles. ${ }^{216}$ Thus, one may fairly assume that SEPTA riders similarly do not qualify as a captive audience for the purposes of newspaper distribution; although they have but one choice in the system, they need not even pick up a copy of the newspaper, whereas radio transmissions automatically hit the ears of Washington streetcar riders.

In light of SEPTA's deal with TPI Metro PA to distribute Metro on an exclusive basis in paid areas and on platforms (now public forums), the agency-notwithstanding an out-of-court settlement removing the case from court ${ }^{217}$-created restrictions on newspaper distribution that should not survive a court's scrutiny.

\section{Public Policy Issues}

The November 2001 out-of-court settlement between SEPTA and the newspaper publishers put an indefinite brake on the Philadelphia conflict. A federal district court has never heard and probably will never hear the case on its merits. Nonetheless, Metro's publisher is anxious to expand quickly into other major urban hubs, and Metro's

\footnotetext{
${ }^{212}$ See supra notes 117-24 and accompanying text (describing the "ample alternative channels of communication" portion of the time, place, and manner test).

${ }^{213}$ See SEPTA RULES, supra note 16, at 6-7 (providing for ways in which publishers may distribute newspapers in stations' free areas).

${ }_{214}$ See Hague v. CIO, 307 U.S. 496, 515 (1939) (Roberts, J., in one of three opinions supporting the result) (holding public streets and parks are traditional public forums).

${ }^{215}$ See 343 U.S. 451, 468 (1952) (Douglas, J., dissenting) ("The streetcar audience is a captive audience. It is there as a matter of necessity, not of choice.").

${ }^{216}$ See id. at 464-66 (upholding the District of Columbia's practice of airing radio programs through bus loudspeakers, making the programs audible to all aboard on the grounds that the right to privacy is diminished when one rides in a public vehicle).

217 Supra note 12 and accompanying text.
} 
troubles in the City of Brotherly Love have significantly impacted the launches of transit dailies elsewhere. ${ }^{218}$ The SEPTA tussle has already prompted the Massachusetts Bay Transit Authority to eschew an exclusive distribution deal with Metro's Boston publisher. ${ }^{219}$ Indeed, Mort Zuckerman decided to distribute his Metro-rivaling Daily News Express-another commuter daily-well away from New York City's Metro Transit Authority's platforms and paid areas. ${ }^{220}$ Essentially, the major newspapers' constitutional challenge to Metro's contract with SEPTA has made public transit agencies and publishers far more hesitant to sign exclusive distribution deals, not to mention ones that offer a measure of editorial control to the transportation systems themselves.

All the same, the lure of replicating the success of Metro in Philadelphia may very well tempt publishers to team up with public transit agencies, notwithstanding a high litigation risk. If a court were to scrutinize such a deal on its merits and ultimately find that the public transit agency violated the First Amendment by prohibiting newspaper distribution in a public forum after entering an exclusive deal, ${ }^{221}$ the agency would face two options: (1) end its contract with the newspaper publisher, stop distribution of the newspaper within the system, and constitutionally continue to ban newspapers from paid areas and platforms; or (2) permit other newspapers into the system pursuant to valid "time, place, and manner" regulations. With regard to the first option, a government entity "may by designation move a public facility ... out of [designated public forum] status." ${ }^{222}$ By way of example, SEPTA may always dissolve the public forum by ceasing to distribute Metro in the disputed forum.

Unless, however, a court were to issue an injunction against a transit system to halt a commuter newspaper's circulation in paid areas and on platforms, an agency would almost certainly select the second option. SEPTA, for instance, stood to lose financially if a court effectively ended its contract with TPI Metro PA. Although this sce-

${ }^{218}$ See supra notes 18-20 and accompanying text (detailing MTG's expansion plans, including an already established Boston Metro).

${ }^{219}$ See supra note 18 and accompanying text (illustrating another public transit system's fears emanating from the SEPTA-TPI Metro war).

${ }^{220}$ See Bercovici, supra note 23 (discussing the distribution structure of the late Daily News Express).

${ }^{221}$ The forum inquiry would, of course, turn on a specific agency's expression regulations. This analysis presumes a marked similarity to those of SEPTA.

${ }^{222}$ SMOLLA, supra note 41 , at 210 (footnote omitted). 
nario adheres to a key principle of press freedom, ${ }^{223}$ it would also generate veritable safety and crowd-flow concerns. The influx of newspaper boxes underground surely would trigger alarms in the minds of safety-conscious officials, who definitely would not want to face the prospect of another costly jury verdict. ${ }^{224}$ To combat rampant expansion, officials could impose "time, place, and manner" regulations that fall in line with the strict scrutiny test for public forums. Such responses potentially could include a permit process with licensing fees, ${ }^{225}$ limits on the number of boxes a publisher places in the system, and mandatory indemnification waivers. Although the number of newspaper boxes would increase, the growth would foster journalistic integrity by countering a public transit agency's propaganda and bolstering First Amendment values.

\section{CONCLUSION}

According to constitutional law scholar Rodney A. Smolla in Free Speech in an Open Society, "[o]ne of the essential preconditions to freedom of speech in a society is the private ownership and control of most mass media." 26 SEPTA's contract with TPI Metro PA to distribute exclusively in a public forum a newspaper over which the agency retains full control curbs First Amendment freedoms and severely harms journalistic ethics. Accordingly, when examining similar deals, courts should guard against the infringement of these liberties by deeming paid areas and platforms limited public forums. They should either order public transit agencies to halt distribution of such commuter

${ }^{223}$ See Lovell v. City of Griffin, 303 U.S. 444, 452 (1938) (“'Liberty of circulating is as essential to [freedom of the press] as liberty of publishing ...." (quoting Ex parte Jackson, 96 U.S. 727, 733 (1878))).

${ }^{224}$ See supra notes 29,55 and accompanying text (outlining SEPTA's precarious financial status). It is highly conceivable that a rider could get injured in the course of other passengers' attempts to take or buy newspapers as they move about a station.

${ }^{225}$ Government agencies should take note, however, "that a licensing fee is permissible, but a state or municipality may charge no more than the amount needed to cover administrative costs." Atlanta Journal and Constitution v. City of Atlanta Dep't of Aviation, 2002 U.S. App. LEXIS 87, at *13 (11th Cir. Jan. 4, 2002) (quoting Sentinel Communications Co. v. Watts, 936 F.2d 1189, 1205 (11th Cir. 1991)). Essentially, the government may charge fees provided that it does "not profit by imposing licensing or permit fees on the exercise of [F]irst [A]mendment rights." Id. Additionally, agency personnel may not possess virtually unbridled discretion to accept or deny applications. See City of Lakewood v. Plain Dealer Publ'g Co., 486 U.S. 750, 769-70 (1988) (invalidating an ordinance affording the mayor the right, without "explicit limits," to reject applications to place newsracks on public property).

${ }_{226}$ SMOLLA, supra note 41, at 209. 
dailies or hold that public transit agencies may not constitutionally bar other newspapers from the disputed forum. By engaging in "the promotion of expression," SEPTA changed the character of the forum at issue. By entering into the contract with TPI Metro PA, the government agency struck a blow to freedom of expression-a fact that should induce courts that subsequently referee comparable exclusivity deals between Metro's publishers and public transit agencies to stop the presses, Metro's. 